Portland State University

PDXScholar

\title{
Alien Land Laws : The Curtailing of Japanese Agricultural Pursuits in Oregon
}

Amy K. Buck

Portland State University

Follow this and additional works at: https://pdxscholar.library.pdx.edu/open_access_etds

Digipart of the Japanese Studies Commons, Legal Commons, and the United States History Commons Comenes know how access to this document benefits you. Network

\section{Rego}

Buck, Amy K., "Alien Land Laws : The Curtailing of Japanese Agricultural Pursuits in Oregon" (1999). Dissertations and Theses. Paper 3988.

https://doi.org/10.15760/etd.5872

This Thesis is brought to you for free and open access. It has been accepted for inclusion in Dissertations and Theses by an authorized administrator of PDXScholar. Please contact us if we can make this document more accessible: pdxscholar@pdx.edu. 


\section{THESIS APPROVAL}

The abstract and thesis of Amy K. Buck for the Master of Arts in History presented July 20,1999 and accepted by the thesis committee and the department.

COMMITTEE APPROVALS:

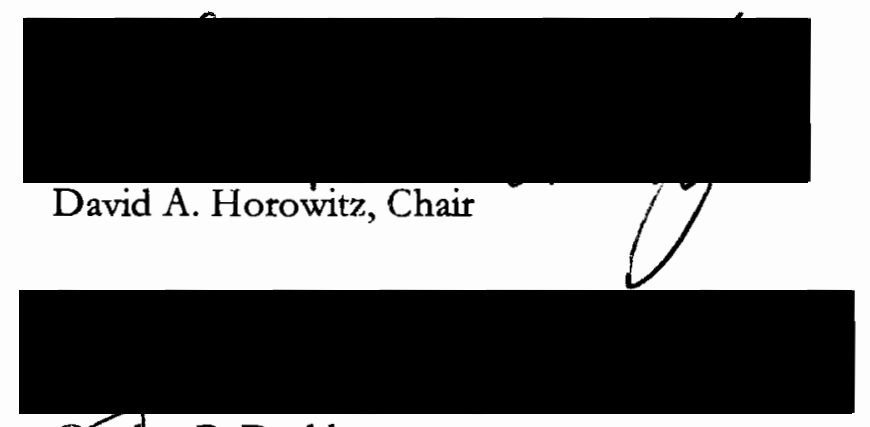

Gorgon B. Dodds

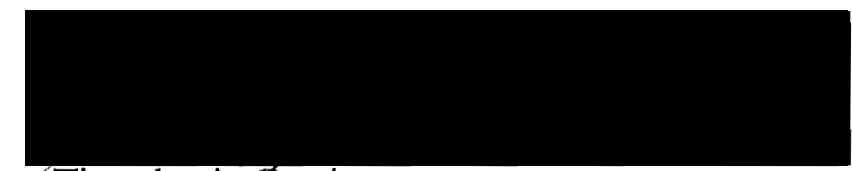

Timothy A. Garrison

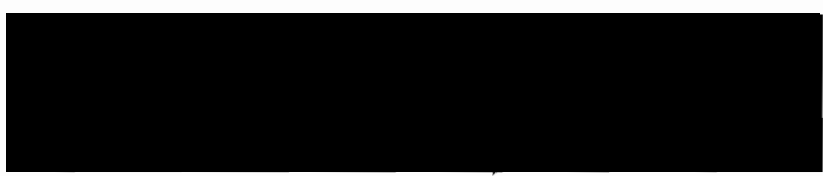

David Smeltzer, Representafive of the Office of Graduate Studies

DEPARTMENT APPROVAL:

Gorgön B. Dodds, Chair

Department of History 


\section{ABSTRACT}

An abstract of the thesis of Amy K. Buck for the Master of Arts in History presented July 20, 1999 .

Title: Alien Land Laws: The Curtailing of Japanese Agricultural Pursuits in Oregon

This thesis describes the evolution and demise of Oregon's alien land laws of 1923 and 1945 and their impact on the Nikkei community and the state's culture.

After a brief discussion of Japanese immigration to Oregon and their lifestyle, the work discusses the emergence of discrimination against Japanese residents. At the same time, it outlines how the Nikkei adopted creative responses to the law. This thesis then explores the manner by which anti-Japanese internment policies during World War II shattered the Issei community, revoking many of the gains made in the previous half-century. The effects of the second alien land law and wartime economic changes in agriculture also are considered. The final section of the thesis deals with successful efforts in reversing the alien land laws and suggests how the Japanese experience in Oregon illustrates the challenges facing a pluralist society. 


\title{
ALIEN LAND LAWS: THE CURTAILING OF JAPANESE AGRICULTURAL PURSUITS IN OREGON
}

\author{
by
}

AMY K. BUCK

A thesis submitted in partial fulfillment of the requirements for the degree of

\section{MASTER OF ARTS in HISTORY}




\section{Table of Contents}

List of Tables

Chapter 1: Introduction 1

Chapter 2: Welcome to America 9

Chapter 3: White Reaction: Discrimination 20

Chapter 4: The Oregon Alien Land Act of 1923

Chapter 5: World Wat II Shatters the Issei Communities 53

Chapter 6: Welcome Home: The 1945 Alien Land Law 64

Chapter 7: Namba v. McCourt: The Land Laws Repealed 78

$\begin{array}{ll}\text { Chapter 8: Conclusion } & 87\end{array}$

$\begin{array}{lr}\text { Sources } & 92\end{array}$

Appendix A: Anti-Asiatic Association of Hood River Pledge Card 108

$\begin{array}{ll}\text { Appendix B: Informed Consent Forms } & 109\end{array}$ 


\section{List of Tables}

Table 1: Crop Failure

Table 2: Japanese Population in Oregon

Table 3: "Non-white" Farmers

Table 4: Acreage of Farms in Oregon

Table 5: Farm Income 


\section{1: Introduction}

White foreigners who are or may hereafter become residents of this state shall enjoy the same rights in respect to the possession, enjoyment and descent of property as nativeborn citizens. And the legislative assembly shall have the power to restrain and regulate the immigration to this state of persons not qualified to become citizens of the United States.

- Article I, section 31, Constitution of Oregon

As the writers of the Constitution of Oregon explained in 1857, white foreigners were welcome to settle in the state but people of all other ethnicities were discouraged from choosing Oregon as their home. This section of the Constitution was only the first of many efforts to restrict minorities from entering Oregon. However, not all attempts were successful. For example, in Truax v. Raich (1915) the United States Supreme Court found that only the federal government could restrict immigration to the United States, forcing states to devise other methods of deterring minorities. ${ }^{1}$

One of the most blatant methods of discouraging people of Japanese heritage from settling in Oregon was the Alien Land Law. This law, first passed in 1923, prohibited Japanese residents from purchasing agricultural land and restricted the amount of time for leases. By 1923 Japanese in Oregon had made gains in the agricultural sector; however, they represented only a fraction of 1 percent of the entire population and operated only a minute sector of agricultural land in the state. Although Japanese

\footnotetext{
1 The United States Supreme Court overturned an Arizona statute that required a minimum of 80 per cent of employees to be citizens. The justices ruled that where one cannot work, one cannot live, and only the federal government has the right to restrict immigration. Milton Konvitz, The Alien and the Asiatic in American Law (Ithaca: Cornell University Press, 1946), 174.
} 
residents, in population and in acres owned, did not threaten to dominate agriculture in the state, legislators and leaders of nativist movements pushed for alien land laws, claiming that if not passed Oregon could become the "new Japan."

Japanese farmers were not a passive group. Their determination and industriousness resulted in continued success in agriculture, despite the laws. By putting land in the names of their American-born children or working on their land under the guise of a sharecropper contract, Japanese agriculturists were able to evade the laws. As more land in Oregon became devoted to raising crops, Japanese farmers continued to cultivate a fair share of the produce. The Great Depression of the 1930s followed years of struggle for all farmers. Harsh weather conditions had destroyed many orchards in the early 1920s. Fruit prices remained below average, intensifying the challenge for farmers. Yet Japanese persevered. ${ }^{3}$

As produce prices became more stable and farmers recuperated from a decade of challenges, they were rewarded with unimaginable discriminatory policies in the 1940s. After the Empire of Japan attacked Pearl Harbor, Japanese residents along the West Coast found their own communities in shambles. As most farmers prepared for record harvests to support Allied troops in World War II, Japanese growers were forced to abandon their farms. The federal government relocated all people of Japanese descent for as many as four years during World War II. Japanese were given little notice of the forced evacuation. Many sold their farms and other belongings for a fraction of their

2 Department of Commerce, Bureau of Census, Sixteenth Census of the United States, 1940, Vol. II, Part 5, Population (Washington, D.C.: Government Printing Office, 1943), 964. C. H. Gram, Tenth Biennial Repont of the Burean of Labor Statistics, from October 1, 1920 to September 30, 1922 (Salem: State Printing Department, 1920), 64.

${ }^{3}$ Minoru Yasui, "We, Too, Please, Are 100 Percent Americans," Sunday Oregonian, 4 February 1930, p. 5. Yasui Collection, MSS 2949, Oregon Historical Society, Portland. 
value prior to leaving, not knowing what to expect in the months or years to come.

Thousands gave up their leases to agricultural land, allowing someone else to benefit from their labor. Others tried to make arrangements with neighbors or farm cooperatives to manage their land while they waited in internment camps. ${ }^{4}$

Internment succeeded where the alien land laws had failed: Japanese residents were finally removed from the Western states. Before the war came to a close, farmers had already begun organizing to keep Japanese away—for all time. The Hearst newspapers kept the issue of the so-called Japanese problem alive. Heeding the press's propaganda, grange associations and legislators called for sending all people of Japanese descent to Japan. In addition, the discriminatory alien land laws were revised.

Preparing for the end of the war, legislators in Oregon passed a revised alien land law in 1945. The stricter law forbade not only purchase of agricultural land, but also the leasing of land. By defining a farmer to be anyone who goes upon or works the land, it prohibited Japanese residents from working on land under the guise of a contract laborer or from acquiring land by placing it in their children's names. Such a broad definition did not allow Japanese residents to assist their children who wished to begin farming, it did not even permit Japanese residents from living in a house that was located on agricultural land. ${ }^{5}$

Once released from internment camps, Japanese who had farmed along the West Coast found additional discouragement. The farm implements, household items, and vehicles they had left locked securely in barns and homes were almost all stolen. Many

\footnotetext{
4 "Farm Income," Oregon Voter 105 (August 11, 1945), 10. "Jap Exodus Starts Here Wednesday," Oregonian, 29 April 1942, p. 1. “Japs' Farms Still Open," Oregonian, 8 May 1942, p. 10.

5 Oregon Laws, 1945, Chapter 436.
} 
faced menacing crowds as they returned to their homes. Some had sold their land and did not have a home to return to. Almost everyone suffered from financial insecurity, as the limited jobs available in internment camps provided trivial wages. These challenges, coupled with the revised alien land laws, crippled the Japanese agricultural communities. ${ }^{6}$

Despite the constant barrage of challenges, Japanese persisted. They organized and prepared to challenge the injustices. At the center of that challenge in Oregon was the movement to test the alien land laws in the courts. With the assistance of the Multnomah County Bar Association, the Japanese American Citizens League brought a test case before the Multnomah County Circuit Court. Like previous challenges, the case rested on the fact that the laws contradicted the Fourteenth Amendment, guaranteeing all residents the right to pursue a livelihood.

Namba v. McCourt, as the case was titled, represented a landmark victory for Japanese and Japanese-Americans. Appealing the circuit court's ruling for the prosecution in the Oregon Supreme Court in 1949, the Multnomah County Bar Association gained its reward. The justices found in favor of the Namba party. Unlike similar cases in other courts during that time, the justices in Oregon not only found in favor of the appellants, they ruled that the entire set of alien land laws, both from 1923 and 1945, were unconstitutional. Shortly after the Court's landmark decision, the Oregon legislature repealed the laws. ${ }^{7}$

Other authors have explored the challenges and contributions of Japanese in the United States. Roger Daniels is one of the first and foremost scholars on the subject of

\footnotetext{
${ }^{6}$ Kennie Namba, interview by author, tape recording, Portland, Oregon, 25 February 1999.

7 Barbara Yasui, "The Nikkei in Oregon, 1834-1940," Oregon Historical Quarterly 76 (September 1975), 253.

"Namba v. McCourt," 204 P. 2 d 569.
} 
Japanese-Americans. Many of his works focus on internment, paying little attention to the decades of discrimination that preceded World War II. One book, Japanese Americans: From Relocation to Redress, is a valuable compilation of essays that one could assume would discuss events after World War II. Although the work addresses new subjects, such as the Japanese presence in Latin America during World War II and the psychological effects of relocation, the focus remains on the war period. Regrettably, the environment Japanese-Americans entered after the conflict is ignored. ${ }^{8}$ Even Daniels' more general book, Asian America: Chinese and Japanese in the United States since 1850, devotes almost onethird of its pages to World War II.

In 1973 Kazuo Ito produced a substantial volume on Japanese-American history, A History of Japanese Immigrants in Nortb America. Ito collected interviews and written statements from hundreds of Issei, or the first generation of Japanese in the United States and created a valuable, although informal, work of Japanese-American experiences.

However, Ito failed to correlate the stories told by the subjects to international or regional events and mentioned legislation and court cases only in passing. ${ }^{9}$

Yuji Ichioka described the Issei in The World of the First Generation Japanese Immigrants, 1885-1924 (1988). Unlike Ito, Ichioka included the details of legislation and court decisions, enabling him to write from both the Caucasian perspective as well as the Japanese perspective. However, Ichioka wrote about events in California and ignored the experiences of Oregon and Washington. ${ }^{10}$

\footnotetext{
${ }^{8}$ Roger Daniels, Sandra C. Taylor and Harry H. L. Kitano, eds. Japanese.Americans: From Relocation to Redress (Seattle: University of Washington Press, 1986).

${ }^{9}$ Kazuo Ito, $A$ History of Japanese Immigrants in North America, trans. Shinichiro Nakamura and Jean S. Gerard (Seattle: Executive Committee for Publication of Issei, 1973).

10 Yuji Ichioka, The Issei: The World of the First Generation Japanese Immigrants, 1885-1924 (New York: The Free Press, 1988).
} 
Frank Chuman turned his attention to legal aspects of Japanese-Americans in The Bamboo People (1976), which focuses on legislation, both state and federal, and court decisions relating to Japanese-Americans. Chuman successfully developed the context for these events by referring to national and global situations. However, most of the book focuses on laws and court decisions arising from California. While this emphasis may have been justified by the fact that California had the largest Japanese population of any state, not to mention the most vocal cries against Japanese residents, one is left wondering if the situation in California were exceptional or if it were representative of the all states. ${ }^{11}$

Charles McClain edited a volume that, like Chuman's, focused on Japanese Americans and their relationship to legal issues. In Japanese Immigrants and American Law, (1994) volume 2, which focused on the alien land laws and related issues, McClain reprinted a series of journal articles published throughout the twentieth century by professionals in the various fields of history, political science, and law. Although the reader is introduced to the varying perspectives of the intellectual class over time, Japanese- American voices cannot be heard. Once again, the focus is on the alien land law in California. ${ }^{12}$

In “Oregon's Japanese in World War II, a History of Compulsory Relocation” (1961) dissertation author MarvinPursinger compiled a useful collection of government documents and newspaper articles, but added very little interpretation to the material. A valuable reference, his work nevertheless offered no mention of the Japanese perspective

\footnotetext{
11 Frank F. Chuman, The Bamboo People: The Law and Japanese Americans (Del Mar: Publisher's Inc, 1976). ${ }_{12}$ Charles McClain, ed. Japanese Immigrants and American Law: The Alien Land Laws and Other Issues, vol. 2 (New York: Garland Publishing, Inc., 1994).
} 
of events, but instead the Japanese were portrayed as victims who took little positive action. Unlike other books focused on internment, Pursinger continued beyond relocation to the return of Japanese to their communities after the war. Yet conflicting information and lack of interpretation raised more questions than answers. ${ }^{13}$

Masakazu Iwata added a unique perspective to Japanese-American books when he chose to focus on the contributions Japanese made to agticulture in Planted in Good Soil (1992). This two-volume work, several decades in the making, combined statistics with Issei experiences and Caucasian attempts to thwart Japanese success. While it is a very thorough compilation, the focus, again, was on California. However, other West Coast states each receive a chapter of the two volumes. Although Iwata incorporated a variety of primary and secondary sources, including several interviews and a Japanese-language newspaper, he relied heavily on three sources for his chapter on Oregon. The chapter also ignored the political situation in the state and confined treatment of the alien land laws to two paragraphs. Since Iwata was concerned with only the Issei, moreover, he provided no information on the period after World War II. ${ }^{14}$

This thesis seeks to balance the voices heard in Oregon during the first half of the century. The laws, written and implemented by white residents, require treatment of the controversy in circles that often excluded Japanese. However, I have attempted to share not only the impact these actions had on the Japanese communities, but also to highlight how the Japanese community responded to and challenged discriminatory measures. In addition, while the focus is Oregon, I have included events that occurred throughout the 
nation and, especially, in California, so that the reader might better understand the context in which Oregon politicians and Japanese residents were acting.

By following the evolution of the alien land laws, political and economic trends in Oregon's history are revealed. Furthermore, learning the Japanese response to these laws and other challenges illustrates how one immigrant group has contributed to the fabric that is Oregon. As the state continues to grow, inviting new residents to its borders daily, an understanding of the injustice other immigrants faced is warranted. Furthermore, an appreciation of the contributions of newcomers helps to facilitate respect for all who choose Oregon as their home. 


\section{2: Welcome to America}

He was born with the fate of being a second son. In nineteenth century Japan, the second son had no reason to be hopeful. Etsuo Namba would not follow in his father's footsteps and own a farm; that would go to his older brother. Etsuo could not hope for a house, for that too would go to his older brother. In fact, all of his parent's belongings would be willed to his older brother, leaving Etsuo with no promise for success. But that did not stop Etsuo from dreaming of the things that his older brother would inherit. At the turn of the century, Etsuo let his dreams carry him to a new land. ${ }^{15}$ In the first years of the new century, Etsuo boarded a ship for America. He was of the first generation that had the option of leaving Japan. In 1868 the Tokugawa period concluded, and with it Japan's isolationism ended. Influenced by Commodore Matthew C. Perry's naval threats, the Meiji Restoration welcomed Western influence. The borders of Japan opened for trade as well as travel.

Just as Japan was granting more rights to its citizens, so the United States was guaranteeing the rights of its citizens. In 1868 the Fourteenth Amendment was ratified. "No State shall...deprive a person of life, liberty, or property, without due process of law," the amendment promised, "nor deny to any person within its jurisdiction the equal 
protection of the laws." The amendment, aimed at protecting the basic rights of African Americans after the Civil War, was one of many Reconstruction measures enacted in the increasingly complex country. As Japanese immigrants began entering American shores, they soon learned that the Fourteenth Amendment may have addressed the rights of African' Americans, but it did not apply to them. In fact, state legislatures along the West Coast passed laws that violated the proviso, such as restricting fishing licenses to citizens. While Japanese occupations were restricted in this manner, their right to purchase land or pursue a career in agriculture was taken away by alien land laws. Livelihoods, liberty, and property were all confiscated from Japanese immigrants and their families because of racial intolerance.

With the Meiji Restoration in 1868, Japanese not only were allowed to emigrate from their island country for the first time, but other changes in the government acted as an impetus to leave. Forced conscription into military service encouraged some to leave the country. Most who left, however, were farmers from the Okayama prefecture in southern Japan. The Meiji Restoration changed the taxation laws so that the land was taxed, not the harvest. Therefore, in years of poor harvests, the farmers did not receive any reprieve from taxes, causing great financial hardship. Furthermore, an increase in population made the competition among farmers on very limited land even more intense. From 1880 to 1920 Japan's population almost doubled. In addition, the Meiji Restoration initiated many deflationary measures, one of the results being a decrease in the price of 
rice. Coupled with the more harsh taxation policy, many farmers were forced to look elsewhere for a source of employment. ${ }^{16}$

[Late-nineteenth century Japanese not only felt the impetus to leave their land, but were attracted to the United States. Pamphlets circulated in Japan touting the money waiting to be earned in America. "Gold, silver and gems are scattered on her [America's] streets. If you can figure out a way of picking them up, you'll become rich instantly to the tune of ten million and be able to enjoy ultimate human pleasures," one popular pamphlet tempted, Tokyo newspapers encouraged young men to travel to America where they could get a Western education or make enough money to live a comfortable life when they returned to Japan. ${ }^{17}$

[Encouraged by these enticements, young Japanese men started sailing from the island's shores in significant numbers in the 1890s. A steamship line between Kobe and Portland, inaugurated in 1887 , transported eager immigrants. A treacherous journey awaited all young men attempting to leave from Kobe; yet the months-long cramped ship ride and days or weeks at the immigration site once on American soil merely foreshadowed the challenges that awaited them. "I had a hard time of it landing in the U.S.," John T. Yoneyama, an Issei, wrote, "and when I finally succeeded I found very many differences between the real America and the America of my imagination." Another Issei remembered the journey in the form of a poem:

Illusion and I

Travelled over the ocean

Hunting money trees. ${ }^{18}$

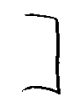

${ }_{16}$ T. Iyenaga and Kenoske Sato, Japan and the California Problem (New York: G.P. Putnam's Sons, 1921), 56. The increase was from 30 million to 55 million people, a result of the change in the feudal hierarchy.

${ }_{17}$ Lauren Kessler, Stubbom Twig (New York: Penguin Books, 1993), 8.

18 Ito, $44,32$. 
By the turn of the century, the census found 24,326 Japanese residing in the United States. During the initial period of immigration, from 1885 to 1907 , the dekasegi period, most of the men who traveled to the United States sought work for a short time so they could earn enough money to return to Japan and live affluently. Others came seeking a western education and planned to return at the end of their formal education. Beginning in 1908 a second period of immigration began. This period, which continued until exclusion in 1924, was characterized by settlement in the United States. After working for several years, Japanese immigrants learned that although jobs were plentiful, financial rewards for labor were scant. Their stay in the United States had to be extended, for many indefinitely. ]

[ Initially many Japanese worked as laborers for the railroads, canneries, or in the timber industry, replacing the Chinese laborers after the exclusion laws of 1882 . Others found work as laborers in the occupation they knew from Japan: farming. A distinctive type of farming had developed in Japan. Throughout the nineteenth century, Japan was an agricultural nation with over half of the population earning wages in that occupation. However, land was limited. In fact, only sixteen per cent of the island's land was suitable for agriculture. To meet the restrictions, a very intensive form of farming developed with three acres as the average size of a family farm in Japan, or about a half-acre per farmer. ${ }^{19}$ Like most of the immigrants from Japan, Etsuo carried little with him on the journey across the ocean other than the skills he developed working on his father's rice paddies.

When Etsuo settled in Oregon in 1908, he found employment on farms. Working as a laborer, he earned $\$ 26$ to $\$ 35$ each month, comparable to the other major 
occupations held by Japanese. ${ }^{20}$ But farm owners noted the efficiency and success the Japanese laborers had in the fields. Soon farmers hired Japanese as contract workers and share tenants. A written contract specified the details, but most sharecroppers worked for a percentage of the crop's value, not just wages. In addition, the owner typically provided the tools and machines needed to farm. As sharecroppers continued to see success, they were able to save enough money to lease land themselves, thus gaining freedom from landlords. However, more desirable was the ability to purchase land. To make purchase of land more affordable, many Japanese formed corporations where they were able to pool their money to buy tracts of agricultural land. ${ }^{21}$ Other Issei with little capital acquired land by working for farmers who paid them in raw land rather than wages. "Originally the Japanese were invited to come [to Hood River] by American landowners who were eager to see their land cleared and, as the result, in many cases, Japanese were given the tracts that they now hold in exchange for their labor," Frank Davey wrote in a report to Oregon's Governor Ben Olcott in 1920. Of course, this required endless hours of work and little reward initially. Oftentimes Japanese worked for a farmer, tried to clear the trees and rocks from his own land and prepare it for planting, as well as working for wages. "Japanese went first into parts where very few farms existed," Davey continued, "The lands were mostly logged off or brush lands, and it was after years of incessant hard labor that they succeeded in clearing these tracts, and

19 Iyenaga, 52-53.

20 O. P. Hoff, Seventh Biential Report of the Buneau of Labor Statistics from October 1, 1914 to September 30, 1916 (Salem: State Printing Department, 1916), 90. Other common occupations held by Japanese immigrants included canneries, timber mills, fishing, and domestic service.

21 C. H. Gram, Ninth Biennial Report of the Bureau of Labor Statistics from October 1, 1918 to September 30, 1920

(Salem: State Printing Department, 1920), 8. 
produced many farms." 22 Once the property was ready for planting, Japanese farmers then had to wait for a year or more before they could harvest their crops. For example, strawberries could be planted and harvested the following year, but apple orchards took approximately seven years to bear fruit. ${ }^{23}$

The persistence of Japanese agricultural efforts paid off. $[$ By 1909 ninety-one Issei in Oregon had achieved the status of independent farmers. They operated a total of 3,205 acres of land, of which they owned 2,048 acres. ${ }^{24}$ Over the next decade, Japanese farmers continued to throw their efforts into their fields. By 1920 Japanese owned 4,702 acres in the state of Oregon. This property was valued at $\$ 142,255$. The following two years Japanese farmers did not purchase more land, in fact, the number of acres owned by Japanese decreased slightly. However, they made substantial improvements to the land they owned. The property value increased by more than half, to $\$ 226,454$ in $1922 .{ }^{25}$

[The devotion that entire families put into agriculture was evident in the success of Oregon's Japanese farmers. By 1920 Japanese farmers in the Gresham area were producing 50 per cent of the raspberries, 90 per cent of the strawberries, and 60 per cent of the vegetables. ${ }^{26}$ However, to attain such percentages of the market came with significant challenges. Often leasing improved land for $\$ 10$ per acre, the Japanese were forced to pay higher rates than Caucasian farmers. Despite these obstacles, Japanese farmers were very successful. Their intensive agriculture style, brought from Japan, helped them use small portions of land to their greatest advantage, as did long hours of

22 Frank Davey, "Report on the Japanese Situation in Oregon," (Salem: State Printing Department, 1920), 14.

23 Namba.

24 Iwata, 222.

${ }^{25}$ C. H. Gram, Tenth Biennial Report of the Bureau of Labor Statistics from October 1, 1920 to September 30, 1922, 59. 
toil by both the husband and wife, and children who were old enough to be of

assistance. "They [the Japanese] are better farmers than white men," one person

observed. "That is, [they] manage to produce more per acre and cultivate more and keep the grounds clean much better than the average white man. In the opinion of most of the white men, the trouble with the Jap is he is too d--- efficient and can make money where Americans would starve.,27

Initially, Japanese entry into agricultural proprietorship did not excite other farmers. [Although Japanese farmers sold their produce for 5 or 10 percent less than other farmers in the Portland area, most notably the Italian farmers, competition was minimal. The Italian farmers excused the Japanese prices, claiming that they were a reflection of the poor quality of the produce, not an effort to slash prices to gain a larger share of the market. Furthermore, competition was limited because of specialization. Japanese farmers concentrated on strawberries and other berries initially, allowing other farmers to produce vegetables and wheat. $\left.{ }^{28}\right]$

Another reason for the Japanese farmer's success were the networks established with other Japanese growers. As early as 1906 approximately half of the Issei farmers had joined farm associations. These organizations assisted the farmer by protecting their common interests and preventing competition among them. Some associations, such as the Lake Labish Issei organization, located just north of Salem, created innovative methods of assisting members, such as setting aside a percentage of the profits to purchase farm equipment for member's use. They also established a system of grading

\footnotetext{
26 Davey, 5.

27 Jan Lynch, North Yakima, to Honorable W. J. McConnell, Moscow, ID, 21 March 1917, MSS 1500, Oregon Historical Society, Portland, 4.
} 
their produce, using the standards to retain customer confidence in the quality of their products. $^{29}$

As the young men who sailed the ocean at the end of the nineteenth century began to settle in their new home, they looked for other aspects of stability, including marriage. Many states had miscegenation laws that prohibited Japanese from marrying Caucasian or African-American women. Therefore, a system was devised for women from Japan to be married to men who were already living in the United States. These women, the so-called picture brides because their spouses knew them by only a picture, then made the arduous journey across the Pacific to an unknown land and an unknown husband.

Etsuo, too, decided it was time to marry. However, his bride, Shizuno, was not exactly a picture bride. Typical of many Japanese marriages, his family had known his wife's family in Japan. In fact, Etsuo probably went to school with Shizuno. While they were still young, before Etsuo crossed the ocean, the families made the wedding arrangements. Etsuo learned that he would need to work in the United States longer than anticipated to make enough money to be successful in Japan. Therefore, in 1914 he sailed back to his native home to marry Shizuno. That same year they returned to Oregon together to start their farm and begin their family. ${ }^{30}$

Once picture brides joined their husbands in the United States, Japanese families grew quickly, and Japanese women began to orient themselves to their new homes. Etsuo's family grew, too and he soon had five mouths to feed. By the mid-1920s Etsuo

${ }^{30}$ Namba. "Law Assailed on Alien Land," The Sunday Oregonian 6 April 1947, p. 18.
} 
had to change his goals. With children to care for, Etsuo stopped thinking about saving money to return to Japan. Instead, he worked to support his family in the United States. His wife, too, adjusted to life in America. [In Hood River, some Japanese formed orientation classes for new immigrants that taught American table manners, child-care for new mothers, methods of entertaining guests, and other American customs. ${ }^{31}$ Japanese mothers learned to cook fried chicken and apple pies and other American staples. Yet much of the Japanese culture was retained by the Issei.

[Like all immigrant groups, Japanese settled in communities with other people of their own nationality. The Japanese language was the primary, and often only, language spoken by Issei. Japanese customs were maintained. While the aroma of apple pie came from some Japanese kitchens, rice was still a staple. And they passed on to their American children the language and culture. Entering first grade, Etsuo's son, Kennie, was more familiar with Japanese than English. Many of his classmates, Kennie recalled, had to spend two years in the first grade because they were not only learning how to read and count, but were speaking the English language for the first time. ${ }^{32}$

As the Nisei, or second generation in America, began attending public schools, their parents feared that they would forget their heritage. Japanese communities formed language schools for their children. Nisei attended public schools to learn English and American culture during the day and then Japanese language schools in the evenings or on Saturday to learn Japanese and Japanese culture. In this manner, Japanese residents ensured that their children grew up knowing the American culture and language, but retained their cultural heritage.

31 Ito, 131. From an excerpt by Shizue Itwatsuki. 
After attending public schools, language schools and any after-school activities, such as football in Kennie's case, Nisei children returned to their homes to help their parents on the farm. "First thing we'd do," Kennie recalled, "is we'd have to go out in the field and help Dad harvest. If we had homework, that came secondary." Much of the work that Kennie and his siblings did consisted of packing the produce for the early morning drive into the market. Before the sun rose, farmers would begin the journey into Southeast Portland where the produce markets stood. They carried on their trucks all the fruits and vegetables that they had harvested the previous day. Without any guarantees of selling their goods, they arrived at the market and waited for the market employees to inspect their produce. "If you had exceptionally good produce they would buy it," Kennie remembered, "but if you didn't, you'd have to take it home again and throw it away." Because there was no refrigeration, produce that could not be sold that day was lost. ${ }^{33}$

By the early 1930 s the marketing process simplified. Rather than pack their produce and take it to market, farmers now sold directly to Safeway grocery stores whose buyers drove refrigerated trucks and stopped at farms in the area. Not only did Safeway thus avoid paying middlemen, but farmers saved the time and expense of driving their produce into Portland every morning. ${ }^{34}$

Not all produce was sold to the market or the Safeway buyer, but some of it was kept for trading with neighbors. Etsuo's farm on Sandy Boulevard produced vegetables, but his Caucasian neighbor had cows and pigs. The farmers would satisfy both their

\footnotetext{
${ }^{32}$ Namba.

33 Ibid.

34 Ibid.
} 
needs by sharing their produce. For example, Etsuo would exchange two feed sacks of potatoes for a portion of a butchered pig, or in the summer, some strawberries for milk. Japanese and Caucasian farmers often operated such a system, helping provide each other with sustenance. ${ }^{35}$

With the agricultural depression of the 1920 s and the Great Depression of the 1930 s, this system of sharing aided farmers who struggled to survive. However, by that time, Japanese had become accustomed to challenges. They escaped the harsh conditions of their native country only to find the journey across the ocean and labor in the United States offered more hope for prosperity than wealth itself. Yet the Issei accepted the challenges, and entire families contributed their efforts to enable Japanese to purchase or lease land for successful farms.

35 Ibid. 


\section{3: White Reaction: Discrimination}

While the personal relationship between Japanese farmers and their neighbors was strong, tensions occasionally arose from the threat of economic competition and discriminatory attitudes based on ignorance. The railroads laid by Japanese laborers opened the West, and represented the close of the frontier. As land was quickly settled by those who took the rails West, as well as by the railroad itself, people began to fear that the United States was becoming too crowded. Farmers, especially, complained about their poor fortunes in the late nineteenth century. A national campaign was organized by Farmers' Alliances, which developed into the Populist Party. In 1892, the party presented its platform, which included limiting immigration and prohibiting land ownership by aliens. The party realized little success in 1892, but its resolutions were not forgotten. Several years later, immigration restrictions and land ownership would be national concerns. ${ }^{36}$

Beginning in 1906, the Federal government imposed immigration restrictions on Japanese, prohibiting the movement of Japanese from Hawaii to the mainland. The following year, Foreign Minister Tadasu Hayaski and Secretary of State Elihu Root further limited immigration in an agreement that Japan stop issuing passports to contract laborers, although the act permitted "settled agriculturists, or farmers owning or having 
an interest or share in their produce or crops," to immigrate. ${ }^{37}$ A year later, the more inclusive Gentlemen's Agreement issued guidelines that restricted Japanese settlement. Only relatives of established Japanese residents, former residents, and settled agriculturists now qualified for passports to the United States. Census records reveal that the agreement was extremely effective; more Japanese left the United States than entered between 1907 and 1913. This informal understanding between the two governments remained in effect until 1924 when all immigration was prohibited by the Immigration Act. $^{38}$

Those who were able to enter the country were confronted with naturalization policies that discouraged their settlement. When Saito, a native of Japan, applied for United States citizenship in 1894, the federal district court in Massachusetts argued whether Saito, whom it termed "Mongolian," fell under the constitutional guidelines for granting citizenship to a "free white person." The court decided that the meaning of the Constitution was to restrict citizenship to Caucasians, and therefore Saito's application was denied. ${ }^{39}$ A generation later, the same question came before the Supreme Court when Takoa Ozawa challenged the courts for citizenship. In a ruling that remained precedent until 1952, the court declared that Japanese were not considered "white" or AfricanAmerican, and therefore could not become citizens. ${ }^{40}$

\footnotetext{
${ }^{36}$ See John D. Hicks, The Populist Revolt: A History of the Farmer's Alliance and the People's Party. (University of Nebraska Press, 1961).

${ }^{37}$ Chuman, 32-33.

38 In 1907 12,888 Japanese immigrants entered the United States. In 1908 the number fell to 8,340 and by 1909 only 1,596 Japanese immigrated. Chuman, 35-36. "Would Bar Asiatics, Reduce All Quotas," New York Times 6 February 1923, p. 5.

39 Chuman, 6-7.

40 Ozawa v United States 260 US 178 (1922).
} 
Discriminatory immigration and naturalization policies reflected the popular culture. In intellectual circles scholars used the nationalistic press and their own publications to tout the peril caused by Japanese. Despite their allied status during World War I, Japan intended to declare war on the United States, some newspapers alleged. Following the war, critics chastised Japan as an imperialistic power in Korea, Siberia and China, yet the most intent anti-Japanese sentiments emerged from nativist and racist ideologists who believed that World War I had weakened the Western World. ${ }^{41}$ Although democracy may have been preserved, it came at a high price. Harvard biologist Lothrop Stoddard published The Rising Tide of Color Against White World Supremacy in 1920, the introduction to which was written by Madison Grant, a zoologist and trustee of the American Museum of Natural History. Grant supported Stoddard's claim that World War I was in actuality a civil war between white Anglo-Saxon men. In such a war, whites were making the world more accessible to other colors, which he divided into red, brown, yellow and black. "Democratic ideals among an homogeneous population of Nordic blood, as in England or America, is one thing, but it is quite another for the white man to share his blood with, or intrust his ideal to, brown, yellow, black or red men. This is suicide pure and simple, and the first victim of this amazing folly will be the white man himself," Grant predicted. ${ }^{42}$

During the 1920s, biologists such as Edward Wiggam toured the nation giving lectures that warned of deterioration of the gene pool by inferior immigrants. The great fear expressed by racial nativists such as Stoddard and Wiggam was that whites would

\footnotetext{
${ }^{41}$ Carey McWilliams, Prejudice: Japanese-Americans: Symbol of Racial Intolerance. (Boston: Little, Brown and Company, 1945),51-53, 58.
} 
lose their own ground in the world struggle not by military defeat but by "the more insidious guise of beggars at our gates, pleading for admittance to share our prosperity." Stoddard argued that World War I had opened the gates further to the yellow and brown people of Asia by creating a shortage of labor, especially in agriculture, which many American farmers sought to solve by the use of Asian laborers. He asserted that the invitation to Asian workers was equivalent to the white man writing his own death warrant. "[N]owhere—absolutely nowbere—can white labor compete on equal terms with colored immigrant labor. The grim truth is that there are enough hard-working colored men to swamp the whole white world," Stoddard warned. To prevent this devastation, tighter immigration restrictions were needed immediately. If no restrictions were put into effect soon, the soul of white people would be destroyed and civilization would collapse. $^{43}$

Fictional works also depicted the Japanese as a menace to society. Two novels appeared in serial form in The Saturday Evening Post and Cosmopolitan in 1921. Both portrayed Nikkei, or Japanese living in America, as greedy, quarrelsome, crafty and suspicious characters. Anti-Japanese fiction also found its way to the big screen. As part of its anti-Japanese campaign, the American Legion released "Shadows of the West," a motion picture that depicted Japanese farmers as spies and conspirators who attempted to control the United States by charging high prices for their farm produce. Japanese growers were shown throwing their crops into the harbor in order to reduce supply and thereby maintain high prices. Furthermore, Japanese were portrayed as criminals and as

${ }^{42}$ Lothrop Stoddard, The Rising Tide of Color Against White World-Supremayy. (New York: Scribner, 1920), xxxii.

${ }^{43}$ Ibid., xxx, 290-295, 271, 254, 299. 
abductors of white women. The American public was to be convinced of the threat Japanese residents posed. ${ }^{44}$

The nativist groups that gained momentum during the patriotic fervor unleashed by World War I further promoted these notions. The American Legion, the resurgent $\mathrm{Ku}$ Klux Klan, and other organizations called for " 100 percent American" and warned of the dangers of a "hyphenated" American society. Irish-Americans, German-Americans, Italian-Americans and Japanese-Americans, argued nativists, possessed a political ideology similar to that of their native countries, and thus presented a threat to democracy. During the tight labor market of the depression nativist groups accused hyphenated Americans of taking jobs from 100 per cent Americans. ${ }^{45}$

Much of the national anti-Japanese propaganda stemmed from the West Coast where California led the political fight against Japanese. As anti-Japanese sentiment became a political issue along the West Coast in the first decade of the twentieth century, discrimination escalated. Political leaders joined with labor unions to create anti-Japanese organizations, such as the League for the Exclusion of Japanese and Koreans. ${ }^{46}$ The San Francisco school board voted to segregate Japanese-Americans in their own grammar schools. Although this effort was defeated, politicians kept the Japanese issue alive, and many discriminatory proposals found support on the legislative floor. In 1909 more than seventeen anti-Japanese proposals came under consideration in California, including bills against immigration, naturalization and owning or leasing land. By 1913 the number of

\footnotetext{
44 McWilliams, Prejudice, 61, 60.

45 David A. Horowitz, ed. "Minutes of the La Grande Ku Klux Klan, 1922-24." Manuscripts Collection, Oregon Historical Society, Portland, 161, 192. "Gifford, Head of K. K. K.," Oregon Voter 28 (25 March 1922), 5.

${ }^{46}$ Ito, 91. California elections were often uncertain, with neither party having an advantage. Therefore, issues such as Japanese immigration were used to tilt the political scales. McWilliams, Prejudice, 23-26.
} 
anti-Japanese bills had grown to more than thirty. Ownership of agricultural land was the dominant subject of these bills. ${ }^{47}$ On May 19, 1913 the first alien land law, the Heney-Webb Alien land law, passed the California legislature. ${ }^{48}$ It prohibited the leasing of land for more than three years by any person who was ineligible for citizenship. Most significant, though, was that ownership of land was strictly prohibited. In reality, however, the law had little impact. "It might be mentioned that the Webb-Heney Act was actually meaningless," author Carey McWilliams wrote, "It merely prevented the acquisition of property in the future. It divested no Japanese holdings. It permitted the Japanese to lease agricultural lands, in unlimited amounts, for a period of three years. There was nothing in the act to prevent the indefinite renewal of leases. It had no effect upon the land situation in California." McWilliams argued that the purpose of the land law was to serve as an irritant to Japanese residents. In fact, the writers of the law admitted that they intended to use the law to force Japanese out of California. ${ }^{49}$

As the first alien land law passed against Japanese in the United States, the HeneyWebb Act had little impact within California, but intense impact in Japan. In fact, after the passage of the law rumors of war between the United States and Japan spread. The Japanese press reported on the law, citing it as one in a string of discriminatory measures directed to Japanese living in the United States. In fact, Japan's anger over the law

\footnotetext{
${ }^{47}$ Chuman, 41, 46.

48 The federal government vehemently opposed passage of the law. William Jennings Bryan was sent to California to urge legislators to defeat the bill, but the Republican governor and his followers saw no advantage in listening to a Democratic president and the bill passed by wide margins in both the senate and house (35-2 and 72-3, respectively). McWilliams, Pnejudice, 45.

49 Ibid., 49.
} 
escalated to the point that Japanese government officials sought out foreign aid that might be made available to them if war broke out between Japan and the United States. ${ }^{50}$

Not satisfied with the legislation enacted prior to 1920 to deter Japanese, many politicians continued to promote anti-Japanese bills. United States Senator James D. Phelan ran his re-election campaign in California on the slogan, "Keep California White." State Senator J.M. Inman from Sacramento headed the organization called the California Oriental Exclusion League. The voters showed their support for the league's program by passing the more restrictive alien land law of 1920 by a three to one margin. Touted as the "final solution" the revised law forbade even the leasing of land by anyone who could not become a naturalized citizen. In addition, it sought to prevent loopholes in the original law. No corporations that were owned by a majority of Japanese could lease or purchase land. Furthermore, Japanese non-citizens who were the parents of citizens could not serve as the guardians of their property. The 1920 law also prohibited the transfer of real property. ${ }^{51}$

Lawmakers in Oregon watched closely as California debated anti-Japanese legislation. In fact, California's governor and legislators urged Oregon and Washington to act accordingly to keep the foreign menace out of the West Coast. While Oregon remained more hesitant that its southern neighbor, it eventually modeled its policies on California's, fostering racial prejudice and discriminatory legislation. Early discrimination was marked by random acts of prejudice, often motivated by economic factors.

In December 1898 four Japanese trackmen who worked for the Southern Pacific Railtoad in Astoria were assaulted by a group of white men armed with hunting rifles. "We'll kill 
you if you don't leave here within thirty minutes!' the men are said to have threatened.

The railroad officers who hired the Japanese laborers halted the incident, coming to the support of their employees. ${ }^{52}$ A similar incident occurred several years later when residents of Toledo responded to the arrival of a group of Japanese by physically removing them from their homes. C.D. Johnson, the owner of the Pacific Spruce Corporation, recruited the Japanese laborers for the "green chain," or most physically demanding labor in his lumber mill. When workers could not be found locally, he turned to labor contractors who suggested he use Japanese labor. The community responded negatively towards a small Japanese community in its midst. Yet Johnson was able to convince the Chamber of Commerce and a few business people that Japanese were the answer to his labor shortage and would not disturb the community. When the newly hired employees arrived in July of 1925, mob violence broke out. A crowd of town members paraded through the streets towards the mill and the newly constructed "Japan town." Although security forces and Johnson himself attempted to stop the rioters, the crowd forced their way to the homes where they threatened the Japanese who were just settling there. The Toledo townspeople collected enough money among them to put all thirty-five Japanese residents on a bus bound for Corvallis, ridding the community of the potential threat of Japanese laborers. ${ }^{53}$

Although not as violent, discrimination in Portland was just as blatant. Many businesses posted signs stating that they would serve "Whites Only." Posters in several 
restaurants declared "No Orientals." ${ }^{54}$ Japanese were not permitted to reside in several neighborhoods. The Oregon Journal ran an article entitled "Realty Board Intends to Stop Sales to Negroes, Orientals" due to perceived depreciation of property values when minorities moved into neighborhoods. "The preservation of property values for Portland's white population was clearly more important than any human concern for the feelings of non-white minorities or even of Orientals," wrote historian Kimbark MacColl. In the Portland neighborhood of Alameda, also, wide-sweeping restrictions barred 'people of undesirable colors and kinds' from owning the newly built homes. Similar restrictions were enforced in the newly constructed Laurelhurst neighborhood. ${ }^{55}$

One historian explained that the nativist tendencies in Oregon resulted from the "covered wagon complex." "The pioneers had brought true Americanism with them and their descendents fought to preserve this purity in the face of an influx of foreign immigrants from the Orient and Southeastern Europe," wrote MacColl. During World War I, these patriotic tendencies shone in Oregon as it led the nation in war bond sales per capita. People in Oregon feared immigrant groups for both defensive and economic reasons. Fear of German spies resulted in Oregon's proclamation 416, which forbade all non-naturalized people of German birth to be within one-half mile of an armory or within one hundred yards of the waterfront. Immigrants were also feared for economic reasons. Unemployment for unskilled and seasonal workers doubled during the recession caused by limitations on shipping during the war. As a result, Portland's export economy suffered tremendously. Foreign exports dropped seventy-seven per cent in 1915-1916.

\footnotetext{
54 Ito, 95, from the record of Shigeru Osawa.

55 E. Kimbark MacColl, Growth of a City: Power and Politics in Portland, Oregon, 1915-1950. (Portland: The Georgian Press, 1979), 269, 70.
} 
Grain and lumber exports fell equally hard, 82 percent and 63 percent respectively. Any added competition for jobs in such a tight economy was unwelcome. ${ }^{56}$

In this atmosphere, the resurgent Ku Klux Klan entered Oregon. With headquarters in downtown Portland, the Klan attracted over 9,000 members in that city alone. Frederick Gifford, Exalted Cyclops of the organization in Oregon, discussed the objectives of the secret order, including opposition to alien or foreign control of American public affairs. While Gifford explained that, in Oregon, this referred mainly to Jews and Catholics, an additional objective hinted that the Klan did not welcome Japanese. "We are also opposed to the ownership of land by aliens, and are in entire accord with the American Legion and its anti-alien land ownership bill," Gifford said. These principles were not discriminatory, Gifford countered, but were "intensely American planks. ${ }^{, 57}$

Like the Klan, the American Legion pledged to work toward containing the potential race problem. However, the Hood River post proposed action beyond property restrictions. In addition to opposing sales or leases of land to Japanese, they favored an amendment to the constitution that would prohibit children of aliens ineligible for citizenship to be citizens, regardless of place of birth. At the national conference in Minneapolis that year, the Legion unanimously voted to support the Western caucus in excluding Japanese, forever barring them from United States citizenship and extending the prohibition to children of Japanese parents. ${ }^{58}$

\footnotetext{
56 Ibid., 139, 138, 143, 38.

57 "Gifford, Head of K. K.K.", 5-6.

58 "Legion Squarely Opposes Japanese," Hood River News, 7 November 1919, p. 1. "American Legion Urges Japanese Exclusion," Hood River News, 14 November 1919, p. 1.
} 
Such blatant displays of discriminatory actions were not limited to townspeople of small communities such as Gresham and Hood River. Oregon politicians avidly supported discriminatory legislation as well. Between 1919 and 1923 several bills sought to restrict the rights of Japanese residents. One measure restricted the issuing of fishing licenses to citizens. In 1920 state senator Colon R. Eberhard (R) of LaGrande, a prosperous eastern Oregon land attorney and future Klansman, introduced a bill to prohibit the employment of aliens ineligible for citizenship on public works The measure's preamble stated it was designed to prevent foreigners residing in Oregon from "crowding out loyal citizens residing at home and abroad during the war with Germany." Eberhard's proposal passed the legislature and Governor Ben Olcott reluctantly signed it in January $1920 .^{59}$

The legislature of 1920 also passed several resolutions regarding immigration. One memorial supported the American Legion's constitutional amendment to make the children of aliens ineligible for citizenship also ineligible, regardless of their place of birth. Another resolution, promoted by Representative Kaspar K. Kubli (R-Portland), recommended limiting the immigration of "undesirable aliens" using this language:

Whereas the people of the state of Oregon believe in an adequate and efficient enforcement of the immigration laws now on the statute books, and the enactment of such additional legislation as may be necessary to bring about the effective exclusion of, and also the deportation from the United States of undesirable aliens, particularly those who are unattached to American ideals and who seek by violent and unlawful means to undermine or overthrow our government...60

It passed with a vote of 25 in support and three absent. 
Governor Olcott opened the 1921 legislature with an address that warned of the growing threat posed by the Japanese population in Oregon, urging law makers to take action "to preserve our lands and our resources for the people of our own race and nationality." ${ }^{\text {11 }}$ Referring to the governor's appeal, Representative Benjamin Sheldon (R) of the southern Oregon town of Medford proposed curbing immigration, asserting that "certain aliens are gaining such a foothold in this section of the United States that they may become a serious adverse factor in the progress of our people toward a higher standard of living and perhaps an actual menace to our American institutions." ${ }^{62}$ The legislator recommended that the governors of the Northwest states arrange a conference for committee members of legislative assemblies to meet and discuss the matter and take action after "careful and painstaking consideration." Sheldon's bill passed by a 50-5 vote.

Politicians acted upon their concern for Oregon farmers in the early 1920s. While farmers struggled to recuperate from the damages of harsh temperatures, the farm index continued to decline, from 205 in 1920 to 116 in 1921. Farmers' purchasing power paralleled the fall from 118 in 1919 to only 71 in 1922 . To better understand the dismal situation of Oregon farmers, Governor Ben Olcott established a Tax Investigation Committee. Senator Walter Pierce and the other members of the committee discovered that farmers in Oregon paid an average of $\$ 303$ in taxes in 1921, while their average net income was only $\$ 463 .^{63}$ Pierce and his colleagues, recalling the dilemmas and demands of the Populist Party, worked avidly to relieve the hardships of farmers. During the

${ }^{61}$ Ben Olcott "Message of Ben W. Olcott to the 31 ${ }^{\text {st }}$ Legislative Assembly," (Salem: State Printing Department, 1921), 17.

62 Journals of the House and Senate 1921, 70.

${ }^{63}$ MacColl, 173. "Farm and Town," Oregon Daiby Journal 26 January 1922, p. 10. "Dynamic Tax System Planned," Oregonian, 25 January 1922, p. 1. Legislators also showed concern for farmers whom they argued 
vibrant gubernatorial campaign in 1922, Pierce used this information to formulate the distinguishing feature of his platform: tax reform that favored over-burdened farmers. Like most of the other candidates, Pierce also represented farmers' interests by supporting a bill that prohibited Oriental ownership of land. ${ }^{64}$

During the 1923 session Representative Thomas H. Hurlburt (R-Portland) introduced a bill to prohibit the issuance of licenses to alien operators of pawnbroker's businesses, pool or billiard halls, card rooms, dance halls, or soft drink establishments. Furthermore, the bill required aliens operating grocery stores, fruit stands and meat markets to post signs stating the nationality of the owners. If alien employees were used in such businesses, the owner was to post a sign indicating their nationality. The legislation contained similar provisions for aliens operating hotels, lodging houses or apartment houses. Supporters urged the necessity of such a law so that "the alien bootlegger" would be driven out of Portland. Others admitted that the bill might be unjust and even unconstitutional, but insisted that it was needed to "eliminate a very vicious class of people." Passed by a narrow vote in the legislature, Governor Pierce quickly signed the proposal into law. ${ }^{65}$

Hulburt's other two bills saw less success. Hulburt was forced to withdraw a bill that prohibited issuing licenses in certain circumstances, almost identical to the above law. House bill 38, which excluded aliens from public work projects, resulted in a similar

had been displaced from the land by Japanese and other aliens while the original laborers served in the war. Miller Freeman, "On Wheelwright Article," Onegon Voter 21 (8 May 1920), 52-53.

${ }^{64}$ Bone, 176+ and Walter Pierce, "Message of Walter M. Pierce to the $32^{\text {nd }}$ Legislative Assembly, convened January 8,1923," (Salem: State Printing Department, 1923).

65 "Swatting the Aliens," Oregon Voter 32 (17 February 1923), 11. Joumals, 1923, p. 40, 186, 317 and General Laws of Oregon, 1923, Chapter 163. 
demise when opponents raised the objection that native-born workers were not willing to perform such manual labor. ${ }^{66}$

The public climate for immigration restriction was reflected in President Warren G. Harding's 1923 visit to Portland. Addressing a crowd of 30,000 listeners gathered at Portland's Multnomah field, Harding insisted on the need for selective immigration. "We were so eager to explore our boundless national wealth, we were so keen for that development which makes communities and in their aggregate makes the greater nation," stated the president, "that we called to the man power of the world to come and participate here." Harding warned that Americans "must guard very zealously against those who work within our borders to destroy the very institutions which have given them hospitality," through a selective limitation of immigration to those of "quaiity," even at the cost of unfilled jobs. ${ }^{67}$

Despite the numerous acts that restricted the rights of Japanese residents in Oregon, the American Legion, the farmer's union, the $\mathrm{Ku} \mathrm{Klux} \mathrm{Klan}$, and politicians insisted that Nikkei still represented a threat to Oregon's citizens. In one such atgument, Kubli repeated a claim that within thirty years California's population would be equally comprised of Japanese and Anglo Saxons. To prevent such a situation in Oregon, the representative urged fellow lawmakers to consider legislation to keep land from alien ownership, warning that the statistics did not allow for hesitancy. ${ }^{68}$

${ }^{66}$ Jowmals, 1923, 38, 304.

67 "Participation in World Court Means No European Entanglement, Says President." Oregonian 5 July 1923, p. 7.

68 Receiving his law degree from Harvard, Kubli retumed to his native Oregon to become a leading printer in Portland. He served in the Oregon legislature, including the honor of being elected Speaker of the House. Like many politicians, Kubli was a known Ku Klux Klan member. "Unanimous Against Japs," Oregon Voter 20 (24 January 1920), 5. 


\section{4: The Oregon Alien Land Act of 1923}

As early as 1911 The Oregonian reported concern about the number of Japanese residents purchasing farmland in the area. The popular phrase "yellow peril" was used to describe the so-called "invasion" of Japanese farmers who were controlling the farms in east Multnomah County. "Whether the effects will be serious or not is yet to be developed," stated the article, but already apparent were the numerous positive effects, including higher rents being paid to the white owners and more productive land. Farmers who rented to Japanese were "taking life easy and getting as much money as if they worked and worried themselves."

As the decade progressed, Japanese continued to pour their efforts into agriculture, and with their success the purchasing and leasing of their own land followed. As native-born Oregonians openly advertised their desire to sell land, Japanese buyers discovered they could impact the market. For example, Minoru Yasui, a prominent businessman in Hood River, received countless letters asking if he or any of his Japanese friends would be interested in buying or leasing farmland in the area. One letter of 1920 asked if Yasui knew any Japanese who might be interested in buying forty acres. People from all over the state wrote to Yasui with similar requests. A man with an orchard in 
eastern Oregon town of La Grande had read in the newspaper about Japanese interest in purchasing land and offered some property to Yasui. ${ }^{70}$

Many potential sellers praised the Japancse farmers for their expertise. Others commented that they preferred Japanese as neighbors to Italians or Irish. Furthermore, some people might have been motivated to sell or lease land due to poor seasons. In 1919 a severe freeze damaged much of the fruit orchards in the I lood River valley. Farmers struggled to recuperate from the devastation, but produce prices in the region remained low for several years. ${ }^{71}$ (See 'lable 1) $\Lambda$ s a result, a fair amount of property transferred hands. Despite the increase in land sales, the number of acres operated by Japanese in Oregon increased insignificantly in the carly 1920s. Yet anti-fapanese sentiment flowed into Oregon from California and Washington.

I'able 1: Oregon Crop Failurc ${ }^{2}$

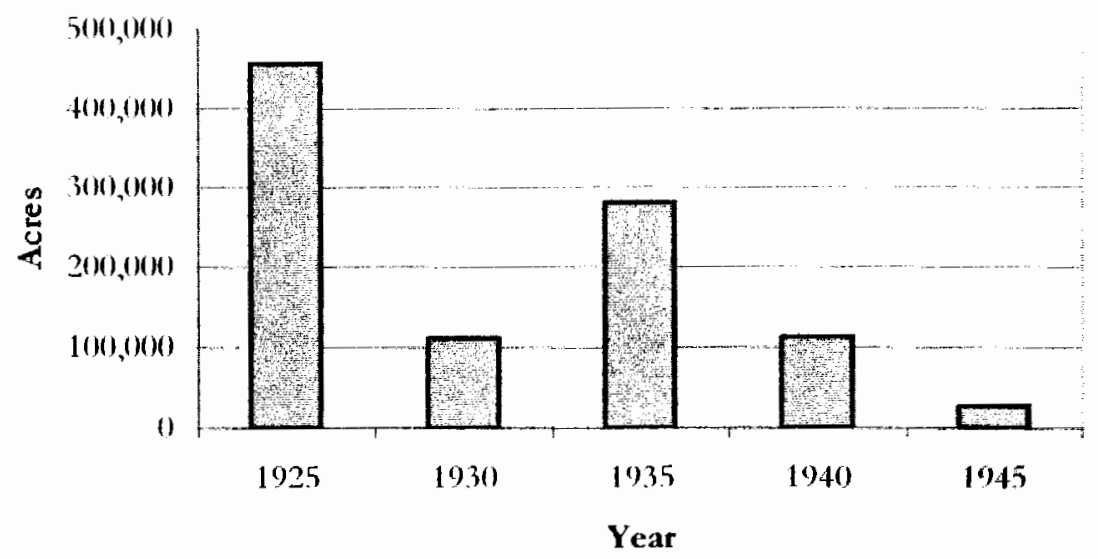

(9) Eugene L. 'Thorpe, "Fast Multnomah Sees Yellow Peril," The Sundoy ()regonian, 26 November 1911, 3, p. 12.

7 Yasui Collection, MSS 2949, Orcgon Historical Society, Portland.

71 Ibid.

72 Department of Commerce, United Slates Censzs of Igriullure, 1945, Vol. 1 Part 32 (Washington, D. C.: Government Printing Office, 1946), 84. 
Early efforts to exclude foreign-born residents from land ownership posed threats to the Oregon economy as well as to national diplomatic interests. When state senator George Wilbur of Hood River introduced an alien land bill similar to the California law in 1917, fellow legislators responded to pressure from President Woodrow Wilson. Oregon legislators were accused of attempting to embarrass the United States with the insulting legislation directed against Japanese nationals during a tense international climate. ${ }^{73}$ Japanese residents also fought Wilbur's bill, issuing a public statement that the foreign population was decreasing, making the law superfluous. (See Table 2 below.) Calling the act blatantly discriminatory, Japanese residents warned of the international repercussions that could follow. ${ }^{74}$ Japanese business leader Minuro Yasui insisted:

It is a fact that in most cases Japanese land owners in this State, hold the cheaper lands such land either, of poor soil or inconveniently located, that White people do not desire to own and cultivate. It seems to me that there is no real reason to prohibit Japanese from owning land, and discriminating against our people and against those of other European nations, unless upon the ground of racial prejudice. It is a very peculiar situation that the majority of the leading citizens of the County in which more than one-half of the Japanese land owners in the State are located, and where the State Senator elected to represent this County, do not favor the bill. There is no organization, commercial or industrial in Hood River County supporting the bill. ${ }^{75}$

73 "Wide Interest in Anti-Alien Bills," Hood River News 21 February 1917, p. 1.

74 "Says Japanese Here Are Fewer," Hood River News 24 January 1917, p. 5.

75 Yasui Brothers, Hood River, to G. Charles Hodges, Stanford, 25 January 1917, Yasui Collection, MSS

2949, Oregon Historical Society, Portland. 
Table 2: Japanese population in Oregon ${ }^{76}$

\begin{tabular}{lrrrrrrr}
\hline \hline & 1880 & 1890 & 1900 & 1910 & 1920 & 1930 & \multicolumn{1}{c}{1940} \\
\hline Total population & 174,768 & 317,704 & 413,536 & 672,765 & 783,389 & 953,786 & $1,089,684$ \\
Total population of Japanese & 2 & 25 & 2501 & 3418 & 4151 & 4958 & 4071 \\
ancestry & 0 & 0 & 10 & 138 & 994 & 2361 & 2454 \\
Japanese-American population & 0 & 0 & 2491 & 3280 & 3157 & 2597 & 1617 \\
Japanese resident population & 0 & & & & & &
\end{tabular}

Forced to withdraw his bill, the frustrated Senator Wilbur warned that the time was coming "when the people will send their legislators here with express instructions to pass just such a bill. I hope, also, that the time is coming when we shall no longer have to submit to the dictation of a foreign country in our internal affairs." ${ }^{77}$ Yet even when the war ended, Wilbur and his supporters did not achieve immediate victory; commercial interests held sway.

The Oregon Voter criticized legislators who supported a bill directed against Chinese restaurant owners, citing economic concerns. "We of the Pacific Coast are endeavoring to get Chinese trade and are eager to participate in the benefits of oriental commerce. Why insult any one oriental race, with one breath while extending a hand for trade with the next breath?" asked the journal. ${ }^{78}$ Again in September 1919, the Oregon Voter reminded readers of the threat to Japanese commerce, recalling the Japanese boycott of San Francisco's ports because of anti-Japanese legislation in that state.

Seattle's port received the bulk of the trade as a result, but because of the rising anti-alien

\footnotetext{
76 Department of Commerce, Sixteenth Census of the United States, 1940, 964.

77 "Wilbur Withdraws Anti-Alien Bill," Hood River News 7 February 1917, p. 1. Throughout the United States, the debate in Oregon was watched closely. When the act failed, many organizations praised the legislators for their "patriotic spirit in putting the welfare of the nation before their individual interests." "Wide Interest in Anti-Alien Bills," Hood River News 21 February 1917, p. 1.

Daniel P. Johnson, “Anti-Japanese Legislation in Oregon, 1917-1923," Oregon Historical Quarterly 97 (Summer 1996), 190.
} 
tensions in Washington, business leaders suspected that Portland could receive an increase in commerce. ${ }^{79}$

Within two months, the Oregon Voter changed its position when it endorsed legislation to restrict Japanese land ownership. As the perception spread that Japanese residents were buying up agricultural property after World War I, the journal expressed fears that the entire Hood River valley would "pass ultimately into the hands of Japanese owners if the present tendency is permitted to develop unchecked." Since a future war with Japan was probable, the editors suggested, it was important that Japan not "possess herself of populous centers and large territory in our coast states." Despite the loss of economic trade with Tokyo and the impact on relations with a potentially threatening country, the Oregon Voter called Americans to protect their citizens and farming valleys:

from encroachments which threaten to supplant the Anglo-Saxon with members of another race and fasten upon the Pacific coast for all time a race problem compared with which that of the south would be in proportion to the comparative intelligence and resourcefulness of the Japanese and the blacks. ${ }^{80}$

Echoing such claims, the Anti-Alien League of Hood River, organized in 1919, called all citizens interested in combating the "Yellow Petil" to league meetings for the purpose of "hold[ing] the home line intact," and preventing further encroachment by Japanese farmers. Complaining that legislation was "exceedingly slow," the League requested that landowners voluntarily not sell or lease to Japanese, whom they claimed had been purchasing land at a rapid pace in recent months. Not only were the white landowners of Hood River threatened with losing their land, but the entire white race 
faced annihilation if nothing were done to curb the so-called Japanese problem. ${ }^{81}$

Using statistics to make their case more sound, the Anti-Alien League reported almost twenty per cent of the births in the region were to Japanese mothers, implying that Japanese were preparing to take over the Valley by sheer numbers. ${ }^{82}$ (See appendix A.) The Anti-Asiatic Association appealed to the farmers' union of Oregon and southern Idaho during their meeting in The Dalles. After listening to several speakers from the league, the farmers agreed to support the aims of the organization, seeking the common goal of protecting their land and produce from Japanese competition. ${ }^{83}$

Japanese residents of Hood River organized to slow the momentum of the antialien movement. In a meeting in 1919, Japanese countered the claim that their foreign population was increasing and dismissed the issue of an increase in land ownership, stating that it was only natural for residents to desire to own land. They admitted that their homes were of poorer quality than average, but argued that the cost of purchasing land, clearing it, and preparing it for cultivation was so high that Japanese farmers required some time to reach a point where they could afford to improve their homes. Despite this urge for patience, all present agreed to organize a better homes and gardens movement, in an attempt to stifle negative comments. ${ }^{84}$

\footnotetext{
81 “Anti-Alien League States Its Case," Hood River News 1 October 1919,p. 4. The league used California as an example of a land being "completely absorbed by Asiatics," waming that the same could happen to their own Hood River Valley if no action was taken to prevent it.

82 "Japanese Statistics Food for Thought" Hood River News 8 October 1919, p.1. While the article remained quiet on the fact that most of the Japanese women emigrated a few years earlier and were now of child-bearing age (while the ages of women in the white community were equally distributed), it did admit that several districts were not included, permitting one to question the validity of the statistics. In addition, the article confused the ensuing debate by reporting that Japanese farmers were not encroaching on land in the valley, but that they owned only two per cent of the tillable land. Of the 51,384 tillable acres in the area, Japanese farmers owned approximately one thousand acres.

83 "Farmers' Union Opposes Japanese," Hood River News 5 December 1919, p. 1.

84 "Japanese Discuss Valley Situation” Hood River News 17 September 1919, p. 1.
} 
Japanese farmers also adopted economic threats in their battle against the AntiAlien league. During the busy fall harvest season, four laborers quit woiking for one of the directors of the league, J. H. Koberg, because of his stance on Japanese purchasing and leasing land. Despite the intentions of the organized Japanese labor to coerce league members into cooperation with potential Japanese buyers, the action only added impetus to the white organization. "[Koberg] will have the sympathy of a large section of the whites here," stated the article, which added that membership was increasing because of the move. The League countered with a telegram to Senator George Chamberlain urging him to pass legislation to curb Japanese purchase of land. ${ }^{85}$

The senator replied that he and his fellow legislators were strongly opposed to Japanese immigration, but that they were bound to the terms of the treaty with Japan when considering laws to deal with the problem. He expressed fear that a war would ensue if the treaty were violated. Although he was anxious for a remedy to the Japanese situation, he wrote that the legislature had not been able to devise an appropriate plan, adding that he was open to suggestions. ${ }^{86}$

Chamberlain's concerns reflected the sentiment that had arisen from the senate in January 1919 when it considered House Bill 3. Introduced by Oregon City's representative, Chris Scheubel (R), the bill sought to prevent Japanese residents from purchasing land. Although the stance was popular among all candidate platforms, the legislators in the current session defeated the bill because of speculation that it would discourage desirable foreign investment. Despite the dominant patriotic motives, some

85 "Japanese Move in Local Problem," Hood River News 1 October 1919, p. 1. 
representatives raised concerns about the racial troubles that would ensue if such a law were passed. Others feared that if challenged, the bill would not be upheld by the courts. $^{87}$

Echoing the state legislators, William D. Wheelwright, former president of the Portland Chamber of Commerce, responded to the Oregon Voter's article that claimed all of Hood River would fall into the hands of Japanese. (See above.) His argument against the alien land laws cited the small number of Japanese residing in the United States, onetenth of one per cent, reasoning that they could not threaten the safety or independence of United States citizens. He asked the readers, "Is there any member of that splendid community of 8,500 souls who occupy the Hood River Valley, who is disturbed as to his own safety because 312 out of the 8,500 are Japanese, and because they farm 1,697 acres out of 30,000 ?" He concluded that the agitation was of political origin, and called for all involved to respect the moral obligation the United States had to Japan and its citizens.

He warned that an alien land law, such as that passed in California, evaded the treaty between the countries and therefore disrupted the good faith of the international comity. ${ }^{88}$

As each side continued to throw statistics and challenges to the other, a nonbiased picture of the situations was called for. Urged by California's governor to investigate the Japanese situation in Oregon, Govemor Ben Olcott requested that Frank Davey report on the sentiments of whites in communities where there was a Japanese

\footnotetext{
86 "Japanese Are Aided by Treaty," Hood River News 28 November 1919, p. 1. The treaty with Japan, signed in 1911, guaranteed subjects of each country the rights of leasing land for residential and commercial purposes. "Full Text of Treaty with Japan," Oregon Voter 24 (26 March 1921), 5, 6.

87 "Alien Ownership Effect on Titles," Oregon Voter 16 (25 January 1919), 24-26.

${ }^{88}$ William D. Wheelwright, "Disapproving Anti-Japanese Agitation," Orgon Voter 20 (14 February 1920), $6+$
} 
population. In 1920, he found that where Japanese worked as laborers, no agitation existed. However, in communities such as Hood River and Gresham, where Japanese leased and owned farmland, strong antipathy existed among farmers, but business interests expressed that they did not believe Japanese to be a menace, and found all dealings with them pleasant. Overall, Davey discovered that people were not bitter towards Japanese on an individual level, but they believed Japanese as a group represented a foreign threat to usurp the region. Davey, however, dismissed the notion that Japanese residents could in fact settle a "new Japan" in Oregon and was quick to point to the many positive effects their communities have made. ${ }^{89}$

Another investigation into the Japanese problem was reported in the Oregon Voter. Economic consideration was only a minor reason for the anti-Japanese sentiment, the article claimed; essentially, it was a racial issue. Citing the unjust history of AfricanAmericans and Native Americans, the author wrote, "If we have many Japanese, we shall not know how to deal otherwise than unjustly with them, and very properly they will not submit. The only real safety is in separation." Because of the threat of such a situation, he stressed that anti-japanese legislation was necessary, but he urged that it be considerate. $^{90}$

After digesting these reports, the House passed an alien land law in 1921. Debate on the bill was intense, as representatives urged patience, allowing the federal government to act on its promise to deal with Japanese immigration. Others stated that Congress showed interest in such laws only because of anti-Japanese actions in California, "and the

\footnotetext{
${ }^{89}$ Davey.

${ }^{90}$ Chester H. Rowell, "Fundamental Reason for Japanese Problem," Onegon Voter 24 (22 January 1921), 54, 48.
} 
Oregon law is just the burr that is needed under the federal saddle, to keep 'er going." Arguments against the bill blamed young veterans for pushing the legislation because they wanted to pursue a war with Japan. Frank Davey contributed his research to the debate, stating that the Japanese could not be assimilated, nor could the American farmer compete with the Japanese who tolerated such low living standards. Again, representatives were reminded of the commercial interests at stake. When the final tally was taken, the bill passed by the narrow margin of 34-25. However, on the senate floor, federal pressure forced defeat of the measure. Although Senator C. M. Thomas (RMedford) expressed fear that the Japanese would flock to Oregon to escape the harsh laws in California, his argument failed to convince his fellow members who were determined to allow the federal government the chance to act. ${ }^{91}$

The following legislature, in 1923, was quick to bring the issue back to the table. In the enhanced nativist climate of 1923 , legislators considered several alien land bills. Representative Edward Bailey (D-Junction City) successfully introduced a proposal that required county assessors to list all Chinese and Japanese who owned, leased or operated real property in the state. The governor signed the bill on February 13, 1923. ${ }^{92}$

When Bailey and Portland Republican Oliver Huston submitted an alien land bill, however, they encountered strong opposition from the Oregon Chamber of Commerce. W.D.B. Dodson, secretary of the Portland Chamber of Commerce, acknowledged that it was important to keep Oregon white and American, but that it was essential to avoid any "additional difficulties" that might impede recovery from the poor export economy of

\footnotetext{
91 The Senate indefinitely postponed the bill, in effect killing it. "Anti-japanese Bill," Onegon Voter 24 (12 March 1921), 32, 34, 35, 37, 39, 41.

${ }^{2}$ General Laws of Oregon, 1923, Chapter 54.
} 
World War I. Another member of the Chamber noted that alien land laws in Washington state had compelled some businesses to move to Portland. "Four times as much wheat and wheat products are shipped from Portland than from Tacoma and Seattle combined," he stated. If the Japanese believed they were not welcome in Oregon, he warned, their business would most likely shift to Vancouver, British Columbia. Chamber of Commerce representative J.W. Ganong insisted that the volume of business outweighed "the troubles incident to their land ownership." The most outspoken representative opposing the bill, D. E. Fletcher (R-Independence), asked his colleagues to be considerate of the Japanese for economic reasons also. Not only did Japanese residents represent customers, but they provided labor in industries, such as the hop industry, where no other workers could be found. ${ }^{94}$

While business interests warned of the adverse economic impacts of an alien land law, the American Legion and $\mathrm{Ku}$ Klux Klan equated the measure with the best interest of white America and pushed for it to be passed unanimously. Ben Dorris, chair of the American Legion's legislative committee, observed that Oregon was the only state on the West Coast without an alien land act. "Without such a law," Dorris warned, "Oregon will soon become the Mecca for the ineligible alien." The American Legion did not intend to hurt industries in Oregon, he concluded, but wanted to see the state remain white and American. ${ }^{95}$

Emphasizing the importance of racial ideology, Hood River Republican Representative L. N. Blowers reminded the house that "there was no cost-plus basis of 
compensation connected with the service of 70,000 Americans who did not come back from France, whence they had gone to keep America for Americans." Japanese residents of Hood River were nice people, he observed, just so long as they remained in the minority. ${ }^{96}$

Nativists persisted in the effort to outweigh the economic arguments against alien land legislation. Seattle city coucilman Tindall warned that the alien land bill was a matter of national defense. "We are in the last line of trench of American civilization," declared Tindall, "California and Washington are calling to Oregon to join with them in completing this defensive position on the coast." Left alone, he wamed, the Japanese would take over the West Coast. "Already the Japanese press speaks about the New Japan.' They openly say in California that when they receive the vote in sufficient number they will open the door," stated Tindall. ${ }^{97}$ The bill's author, Huston, added that in California the Nisei had 40,000 votes, and within a few years they would be in a position to control the state government. "I'm not an alarmist," he insisted, "but I've looked into the situation." Co-sponsor Bailey echoed his colleague, adding that the Japanese would own the entire Willamette Valley within twenty-five years if no action were taken. ${ }^{98}$

Local newspapers ran articles that only added fire to the debate. An article in the Gresham Outlook in 1923 announced the recently released Bureau of Labor report for the state of Oregon, but included only the statistics for Chinese and Japanese residents. While the population of Japanese rose only minimally between 1920 and 1922 (from $4,547$ to 4,614$)$, the increased value of property owned by Japanese showed a dramatic 
rise. In 1920 the report found that the total property value, including lots and acreage, for Japanese living in Oregon was $\$ 168,171$. Two years later Japanese owned lots and acreage valued at $\$ 401,080 .{ }^{99}$ Similar statistics were reported in Hood River, where Japanese initially worked as wage laborers. Only five of the 196 Japanese residents of Hood River in 1920 were employed in fields other than wage laborers. Within three years, 85 per cent of Japanese men in Hood River were involved in agriculture. Of these men, about 60 per cent owned or leased their own land. ${ }^{100}$ While accounts of what competitors thought of as encroachment furthered the notion that action had to be taken to stop Japanese from colonizing the entire West Coast, newspapers also showed concern for their communities, including the Japanese residents. As debate continued on the alien land bill, the Hood River News asked the senators if the law would require any land already owned or leased by Japanese to be confiscated and resold to a legal buyer. The reporter received conflicting answers, and urged that an amendment to the legislation be included to protect the land currently in the hands of Japanese farmers. ${ }^{101}$

Rather than appealing to the state legislators, Japanese farmers in Hood River attempted to compromise with the Anti-Asiatic Association. In a vain attempt to defuse the Oregon controversy without an alien land law, the Hood River Japanese Farmers Association proposed that Japanese would voluntarily prohibit further purchase of land by immigrants and prevent any further influx of Japanese nationals. The Anti-Asiatic Association dismissed the proposals, arguing that they were too vague. ${ }^{102}$

\footnotetext{
99 "Population Given of Japanese and Chinese," Gresham Outbok, 30 January 1923, p. 1. 100 Johnson, 182-183.

101 "The Anti-Japanese Bill," Hood River News 16 February 1923, p. 4.

102 "Asiatics to be Heard," 31 January 1923 and "Japanese Proposal to Stop Agitation Meets with Delay," 31 January 1923, (Newspapers not known), Yasui Collection, MSS 2949, Box 6; Oregon Historical Society, Portland.
} 
Influenced by the Anti-Asiatic Association, the Ku Klux Klan, the American

Legion, and Governor Walter Pierce, the legislature prevailed over Japanese and commercial interests by passing the alien land law in February 1923. Modeled after California's legislation, the measure prohibited the ownership of land by any person who was ineligible for citizenship. Similar to California's law, corporations comprising a majority of aliens ineligible for citizenship could not possess an interest in property other than specified by the existing treaty between their government and the United States.

The Oregon statute also forbade aliens ineligible for citizenship from being the appointed guardian of the estate of a minor. Furthermore, leasing of agricultural land was prohibited. ${ }^{103}$ State Senator Wilbur, a long-time champion of such a bill, termed passage of the alien land law the "first step" in checking Japanese farming and warned that the Japanese were solely responsible for determining whether additional laws would be necessary. "If they are prepared to accept the new law in the spirit in which it was framed, no new legislation will be necessary," he stated. "If, however, they attempt to bridge this law by utilizing willing Americans to act as dummies on land sales and leases, more restrictive laws will undoubtedly be framed."104

As Wilbur forewarned, Japanese residents began avoiding the spirit of the land act even before it went into effect. The law did not remove real estate from any Japanese resident already owning land. Therefore, in order to secure property, many Japanese residents took advantage of the measure's three-month grace period. Several deeds were recorded at the Hood River courthouse in February of 1923, transferring land from Japanese residents to Japanese-Americans or other citizens. Others quickly purchased 
land while it was still legal. Masuo Yasui, prominent businessman and landholder in Hood River, purchased a thirty-acre plot of land in Dee in what was termed, "one of the most important transfers of orchard land." In other transactions, Yasui bought nearly two hundred additional acres. ${ }^{105}$

Supporters of the alien land law criticized both the Japanese farmers who were purchasing property and the cooperating realtors. The American Legion stated that such sales were a flagrant violation of the spirit of the law and resolved to investigate any such transactions and attempt to desist the involved parties. The Hood River Legion went so far as to contact the realtor involved in some of the land sales at his home. When the group requested that the realtor sign a written agreement to refrain from additional land sales to Japanese, the businessman refused, stating that many realtors were involved in such actions, and until they were willing to forgo the profits made from such legal sales, he was going to continue the practice. The Hood River realtor was one of many people willing to ignore the land law because it served no financial benefit. Japanese produce was competitively priced, aiding consumers, and Japanese farmers often paid higher leases for land than white producers, thereby aiding landowners. For Japanese residents of agricultural areas, moreover, new careers were not an option. As one immigrant recalled, "For the average Issei there were just jobs for the lower class people, and consequently, changing one's employment was very difficult."

104 "Anti-Alien Bill Passes Senate," Hood River News 16 February 1923, p. 1.

105 "Local Japanese Anticipate Law," Hood River News 23 February 1923, p. 1. "Japanese Buy Hill Ranch at Dee," Hood River News 23 February 1923, p. 1. Johnson, 202.

106 "Land Transfers to Aliens Opposed," Hood River News, 6 April 1923, p. 1. "Legion Protests Land Sales to Aliens," Hood River News, 27 April 1923, p. 1. McWilliams, 65-66. Ito, 165. 
Japanese residents also evaded the land act's provisions by securing the birth certificates of their American-born children. ${ }^{107}$ With this evidence, they could continue to purchase and farmland by giving it to their offspring, in whose name the title would be held. ${ }^{108}$ Etsuo Namba chose this method to keep the small portion of land he owned in Gresham. After the land law passed, Etsuo put his property title in the name of his eldest daughter. ${ }^{109}$ Correspondence to Yasui reflected this practice. For example, letters asked if he knew of any "American born Japanese" or "a legal buyer" wishing to purchase orchards. Yasui continued to receive letters asking for persons interested in purchasing or leasing agricultural land, many with no reference made to accommodate the law. ${ }^{110}$

Issei found another way to circumvent the law by entering into verbal agreements with parties wishing to sell or lease land. A letter to Yasui from George Sheppard of Hood River exemplified such an arrangement. After planning to lease twelve acres to Mr. Nishimoto, a local Japanese farmer, Sheppard discovered that Oregon law would not permit the lease. "I suggested that our agreement be verbal," he wrote to Yasui, "I suggested that he could come to you and perhaps you would help him look me up as to my honesty." Sheppard offered to market all produce in his name, as well as collect the money and pay the labor checks for harvesting. Nishimoto would be paid two-thirds of

\footnotetext{
107 Yasui Collection, MSS 2949, Box 5, Oregon Historical Society, Portland.

${ }^{108}$ The California Supreme Court found the portion of the law that prohibited aliens ineligible for citizenship from being the guardians of the estates of minors unconstitutional. In the 1922 case, The Estate of Tetsubumi Yano, the court stated that only if one were unfit as a parent could he or she be denied to be the guardian of a minor.

109 Namba.

110 Yasui Collection, MSS 2949, Boxes 6 and 7, Oregon Historical Society, Portland.
} 
the net proceeds, as agreed in the original lease. "By this plan it would appear to everyone...that Mr. Nishimoto is working for me," Sheppard concluded. ${ }^{111}$

Many Issei executed written contracts similar to the arrangement described by Sheppard. Under the guise of sharecropping, the Japanese farmer retained the same responsibilities and most of the same benefits as he possessed before the law, but a friend or neighbor held the title to his property. For example, an employment agreement between Mrs. W. S. Dowd and Mr. E. Suzuki, dated June 6, 1936, allowed Suzuki to receive all income from fruit, berries and other products of her farm and orchard. In return, Suzuki was to furnish all labor, supplies and equipment, as well as to maintain the equipment and buildings. "Mr. E. Suzuki is to have full and uninterrupted [sic] control of all land and buildings belonging to Mrs. W. S. Dowd at her place at Parkdale, Oregon," the agreement read. Mrs. Dowd retained only the right to sell the property. ${ }^{112}$ Other Japanese farmers evaded the law by forming a paper corporation with American citizens in the majority. When methods of avoiding the land law were not available, Japanese settlers had the option of relocation. As news of anti-Japanese sentiment in Hood River reached all of Oregon, as well as other parts of the country, offers to sell land poured in. Yasui received a letter from a Mr. Hickle in Vermont who had heard about the land act. "I had Japanese neighbors for some years and found them very good citizens," he wrote, "Therefore I do not sympathize with the recent movement which I think is activated by jealousy of the success of the local Japanese farmers." The writer then offered to sell his farm, adding

111 George Sheppard, Hood River, to Minuro Yasui, Hood River, February 1929,Yasui Collection, MSS 2949, Oregon Historical Society, Portland.

112 Yasui Collection, MSS 2949, Box 9, Oregon Historical Society, Portiand. 
that the treatment received by the Oregon Japanese was unjust."113 A farmer from the Rogue River Valley also wrote to Yasui and bragged about the good soil, irrigation, climate, and lack of anti-Japanese sentiment in Southern Oregon. ${ }^{114}$ Despite such practices, however, the land law offered little security to Japanese farmers. "Really, every farmer lived in fear and trembling," remembered one Japanese grower. ${ }^{115}$

Masuo Yasui predicted in 1917 that a law preventing Japanese residents from owning or leasing land in Oregon would have little impact on them. After May 25, 1923, his speculation proved to be more true than falsc. Even after the law was cnacted many Japanese, including himself, continued to buy property (in other's names), maintain their own interest in property already purchased, or made share cropping arrangements that allowed leasing of land without calling it a lease. (See Tables 3 and 4.)

Table 3: "Non-white" Farmers"

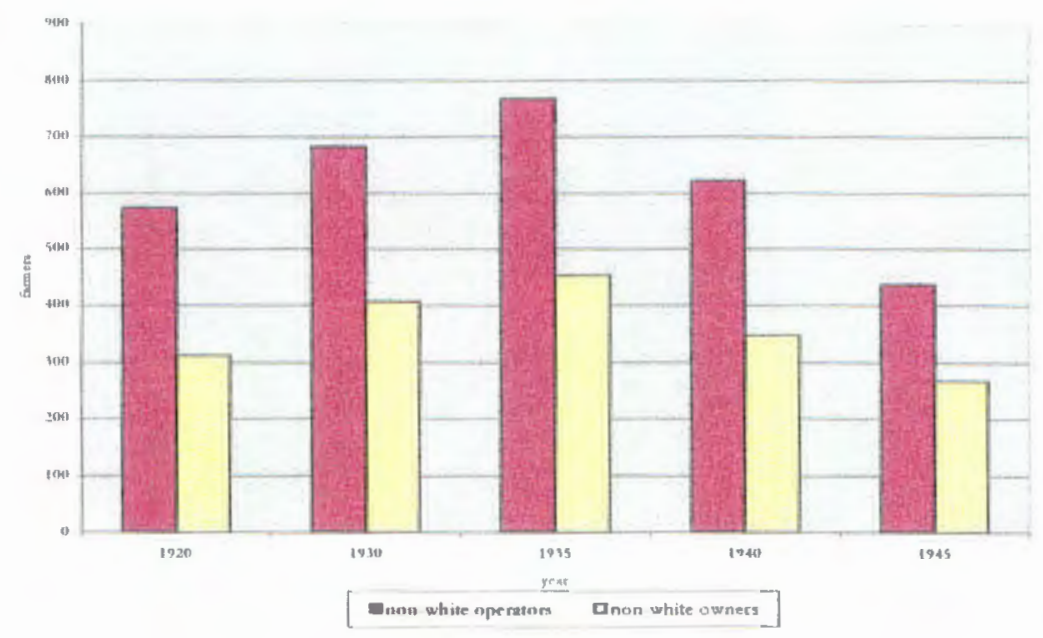

113 Yasui Collection, MSS 2949, Box 4, Oregon Historical Society, Portland.

$11+$ Yasui Collection, MSS 2949, Box 4, Oregon Historical Society, Portland.

115 Ito, 165-66. 
Table 4: Acreage of farms in Oregon ${ }^{117}$

\begin{tabular}{rrr}
\hline & Acreage of all farms & Acreage of Japanese farms \\
\hline 1920 & $13,542,318$ & 8,080 \\
1930 & $16,548,000$ & 8,001 \\
1940 & $17,988,307$ & 11,654 \\
\hline
\end{tabular}

While the economic impacts of these laws may have been minimal, the psychological impact was certainly great. Since their arrival in the last decade of the nineteenth century, the Japanese government carefully followed immigrants' behavior and status. It funded reports on the lifestyles of immigrants living in America, investigated claims that gambling and prostitution were rampant in Japanese communities, and sent questionnaires to those living in the United States inquiring as to their lifestyle and acceptance. When the alien land law was first passed, the Japanese government sent a questionnaire to all those living on the West Coast asking if they were treated with respect. One question specifically asked what the impact the alien land law had on Japanese farmers. Other questions sought information about landlords' attitudes towards Japanese farm laborers and the relationship between Japanese and white laborers. ${ }^{118}$

Long before forced evacuation during World War II, Japanese living in the United States could be heard mumbling "Shikata ganai," or "It's beyond our control." While such a statement could be interpreted as resignation, for the Japanese it only meant that they needed to work harder than before to prove themselves despite the circumstances.

116 Department of Commerce, Urited States Census of Agriculture, 1945, 85, 92. 


\section{5: World War II Shatters the Issei Communities}

Oregon's Japanese population realized their worst nightmares when Tokyo bombs destroyed the United State's Pacific naval base at Pearl Harbor in Honolulu. For those who had been reading the comic books or gum wrappers that portrayed Japanese as monster-like creatures violently attacking Americans, Pearl Harbor only proved what they already knew of the Japanese. For other Americans, such as Kennie Namba, it changed his life. Until that time, Kennie had attended Gresham Union High School where he played on the football team and socialized just like the other students. On December 8, 1941, he first realized that he was not just like the other students, his parents were from Japan. Kennie would not graduate with his classmates at Gresham; instead, he was forced to finish high school in southern Idaho at the Minidoka internment camp. ${ }^{119}$

Following Pearl Harbor, President Franklin D. Roosevelt issued a proclamation declaring that all Issei were "enemy aliens." Seven hundred Japanese immigrants immediately were arrested and detained for suspected involvement with the Tokyo government. Yet newspaper editorials, government officials, and the Nisei pictured the Japanese danger as a foreign matter, not a domestic threat. ${ }^{120}$ Lt. Commander Ringle of

\footnotetext{
119 Namba.

${ }^{120}$ Cliff Lewis, "John Steinbeck's Alternative to Internment Camps: A Policy for the President, December 15, 1941," Journal of the West 34 (January 1995), 56.
} 
the Navy Intelligence optimistically suggested that the war would be the true test of Japanese-American's loyalty. "Whether the younger and succeeding generations are truly American in thought, word, deed and sentiment will depend on the way in which they are treated now, and on how they are helped to meet the test of this war," stated Ringle. ${ }^{121}$

Portland newspapers adopted a cautious stance to the domestic implications of the Japanese threat. A letter to the editor from a school teacher in Portland told the story of a classroom discussion about the Japanese enemies. At the end of the discussion, the teacher saw one of her students, a girl of Japanese descent, crying in the corner. When she confronted her after class to inquire as to what upset her, the girl responded that she believed her fellow classmates were talking about her. The teacher eased her worries by stating that the other students did not consider her Japanese, but merely another American student. The girl proclaimed, “'Oh, I am an American,' in as proud a voice as I have ever heard," reported the teacher. The letter writer suggested offering protection and understanding to such people as her star student. "Liberty has taken them under her wing and they are our own, not to be criticized and isolated because they had their beginning in a despised and hated country, but rather to be included in our fight for the principles which they, too, love.... When we have forgotten the principle of freedom for which we are fighting, there is no longet any need of fighting," the teacher concluded. ${ }^{122}$ Offers of understanding appeared in a full-page article in the Sunday Oregonian in early 1942 that urged citizens and politicians to consider those of Japanese origins loyal until proved otherwise. The reporter noted that no outbreaks of anti-Japanese violence had

${ }^{21}$ Dillion Myer, Uprooted Americans: The Japanese Americans and the War Relocation Authority during World War II. (Tucson: University of Arizona Press, 1971), 70.

122 Anne Chambers, "The Loyal Japanese" Letter to the Editor, Orgonian 29 January 1942, p. 8. 
occurred locally and that no instances of intolerant treatment of Japanese children had surfaced in the schools. ${ }^{123}$

Despite such toleration, the Japanese community in Oregon was severely disrupted by news of Pearl Harbor. All Japanese residents found their financial and commercial transactions frozen immediately after the bombing. Licenses to operate businesses were revoked temporarily, and Japanese-owned businesses reported significant losses even after being able to reopen. "Patronage in Japanese restaurants, stores and other businesses has dwindled to a half or less of previous volume," a reporter stated, "Japanese produce rots on the farms and Japanese clerks and laborers have been replaced by Chinese and Filipinos in many instances." Japanese business owners could no longer get credit, suppliers stopped serving many Japanese, and insurance agents refused to cover them. Some laborers who reported to work as usual on Monday December 8 were sent home until further notice. ${ }^{124}$

The war induced terrible anxiety among Japanese residents. "We were all terrorstricken at the news," a farmer from Hood River recalled, "War between America, where we would live until death, and Japan, where we came from! I am a Japanese subject, but my children are Nisei, and American citizens."125 "We have spent two-thirds of our lives in the United States and we feel we are more American than Japanese," another immigrant told the Oregonian. "We are willing to do anything we may be asked to do to help our foster mother." A mass meeting of Issei sent a group telegram from Portland to

${ }^{123}$ Herbert Lundy, “A Test for U.S. Tolerance,” Sunday Oregonian 4 January 1942, n.p. 124 Ibid.

125 Eiichiro Azuma, “A History of Oregon's Issei, 1880-1952," Oregon Historical Quarterly 94 (Winter 199394), 341 . 
President Roosevelt in January of 1942 that pledged their loyalty to the United States. ${ }^{126}$

In Hood River, Issei signed a similar pledge:

Most of the alien Japanese residents are devoted to this great Democratic America although we are not eligible for citizenship. We love this country so much that we wish to live here permanently...endeavoring to prove our destinies common with that of the American public....The local Japanese have signed with the local civilian defense committee to volunteer for whatever purposes called upon....May we pledge our loyalty to the Stars and Stripes just as do our children who are patriotic American citizens, with our prayer for a more peaceful kingdom on earth, which is the divine bequest of the American people for future generations. ${ }^{127}$

In February 1942, Secretary of War Henry L. Stimson warned that Americans could not "discriminate among our citizens on the ground of racial origin."128 Yet two days later a columnist for the San Francisco Examiner called for "the immediate removal of every Japanese on the West Coast in a point deep in the interior. Herd 'em up, pack 'em off and give 'em the inside room in the Badlands. Let 'em be pinched, hurt, hungry, and dead up against it.” National columnist Walter Lippman also suggested that fifth column activity should be feared and that the Japanese were sure to strike. On February 13, 1942 California Congressmen ordered the "immediate evacuation of all persons of Japanese lineage and all others, aliens and citizens alike, whose presence shall be deemed dangerous or inimical to the defense of the United States from all strategic areas."

The California resolution inspired the abandonment of caution in regard to Japanese residents. In a complete reversal of his previous statement, Secretary Stimson now warned that "racial affinities are not severed by migration. The Japanese race is an

\footnotetext{
126 "Portland Japanese Reaffirm Loyalty to United States," Oregonian 24 January 1942, p. 4.

127 Azuma, 342.

${ }^{128}$ Geoffrey S. Smith, "Racial Nativism and Origins of Japanese American Relocation," in Japanese Americans: From Relocation to Redress, eds. Roger Daniels, Sandra C. Taylor and Harry H. L. Kitano. (Salt Lake City: University of Utah Press, 1986), 82.

129 Myer, 18, 22.
} 
enemy race, and while many second- and third-generation Japanese born on United States soil, possessed of United States citizenship have become 'Americanized,' the racial strains are undiluted....It therefore follows that along the vital Pacific Coast over 112,000 potential enemies of Japanese extraction are at large today." American Legion groups across the country began demanding the immediate evacuation of all people of Japanese descent. In Portland Mayor Earl Riley echoed the Legion's cry by calling Japanese presence in Oregon a national security threat. A survey of Portland citizens revealed that the populace had changed their minds, too. Eighty per cent of those who had an opinion in the survey favored the removal of all enemy aliens. ${ }^{130}$

One day after Japan dropped its first bomb on the Philippines in February 1942, President Roosevelt signed Proclamation 9066. The order established military zones on the western coast of the United States and allowed for the evacuation of all citizens or aliens from such regions. Tensions heightened when Golita, California subsequently was shelled by an enemy seaborne craft thought to be Japanese. Two days later five unidentified airplanes were spotted over Los Angeles; the obvious assumption was that they were also Japanese. In the frenzy that ensued, numerous items reportedly incriminated people of Japanese descent. Seized Japanese documents from Netherlands East Indies had been collected in a "white book" that proved Japan's ten-year preparation for the war, including espionage and fifth column strategy. Japanese tourists, consulates, scientists, commercial firms, and fishermen residing in Netherlands East Indies allegedly helped their native government, going so far as to attempt to alienate the native

130 Smith, 82. Azuma, 343. Gordon M. Connelly, "Survey Reveals Portland Favors Removal of Aliens," Oregonian, 12 February 1942, p. 1. The survey also asked respondents if they favored removing the citizen children of aliens, to which sixty-four percent with opinions objected. 
population there from its Dutch loyalty. The Oregonian reported a kimono found in Portland that had been purchased in Kyoto in 1937 with pictures of a German child, an Italian child, and a Japanese child playing together and flags from the Axis countries shown on another panel. ${ }^{131}$

With such evidence, West Coast politicians criticized the military and the Department of Justice for moving too slowly to deter the threat of Japanese living in the United States. Representative Carter's (CA) bill to appropriate funding for the investigation of people of Japanese descent on the West Coast passed the House unanimously. "This is no time to apply civil liberties on unquestionable citizenship such as the Japanese present," declared another California congressman. "No one with any knowledge of Japanese psychology can apply the complete significance of civil liberties in this case because it constitutes a national hazard."132

In Portland, a handful of people spoke out against interning people of Japanese descent. Two church ministers and an editor for the Oregon Journal were among the few who termed the policies fascist and worried about their racial implications. Mabel Downs, the former dean at Lincoln High School, also denounced the policy of internment and later moved to teach those interned at Tule Lake Relocation Center in northem California. E.B. MacNaughton, president of the First National Bank in Portland, warned the Oregon legislature that racial prejudice must not influence wartime policies. "Racial problems are not easy to solve," MacNaughton admitted, "but the careful approach of dignity and decency will do far more to bring about the human 
understanding which enables neighbors, and peoples, to get along together in order and peace than will the indulgence of emotional outbreaks of bigotry and intolerance."

Former Governor Charles Sprague also spoke in defense of the Japanese living in Oregon. He criticized former governor Walter Pierce for urging Congress to deport all people of Japanese descent and forbid residency in the United States after the war.

Sprague noted that the Japanese population in the United States was too small to be considered a menace. He also cited that those American citizens of Japanese ancestry were American, in spirit and dress. ${ }^{133}$

Pierce responded to Sprague's editorial in the Statesman, arguing that Sprague was ignorant of the threat presented by the Japanese. "This is the most serious threat in our history and it comes from an aggressive, militaristic nation....The Japanese are enemies in our midst; this war is just a dress rehearsal, sortie for supplies," Pierce wrote. Convinced that the Japanese's ultimate goal was to dominate Oregon, he urged that the sale of land to people of Japanese descent must cease immediately.

The man who makes the first sale to Japanese is foully unpatriotic, as he created a Japanese settlement in which Americans cannot live and rear families. The first sale imperils other landholders and they have no alternative but to sell. The neighborhood sinks to the Japanese level and becomes an outpost for penetration.... The alien Japanese must go back to Japan. If necessary, we must amend our constitution so that the accident of birth will not give American citizenship to those whose parents are not eligible to citizenship through naturalization. ${ }^{134}$

Pierce's argument ultimately won out over Sprague's. Under executive order 9066, West Coast evacuation began en masse on March 23, 1942. In all, 120,000 people of Japanese descent, most of them United States citizens, were forced to leave their 
homes. In May Oregon officials quickly attempted to transform the Pacific

International Livestock Exposition Center stables in North Portland into temporary

homes for thousands of Japanese forced to evacuate their homes and property. ${ }^{135}$

Preparing for the uncertainty of the future, some Japanese hastily sold their residential or commercial property for a fraction of its value immediately following executive order 9066 . Those who still owned property when evacuation arrived found the government ill-prepared to handle it. As a result, businesses and residences passed through the care of numerous government agencies. Not only did property loss increase each time it switched hands to a new agency, but the agencies could not prevent acts of vandalism by anti-Japanese groups. The War Relocation Authority (WRA) finally came to safeguard the property in the summer of 1942; but by this time, the Japanese had already been evacuated and much of their property lost or vandalized. ${ }^{136}$

For the Japanese farmers who had spent a lifetime struggling to lease or purchase farmland, the evacuation policies were devastating. Etsuo Namba had sixty acres of leased land, as well as a smaller partial of property that he owned. Like most Japanese farmers, he was forced to give up his lease, losing the time and money invested in the property. In Oregon, many who owned property looked to sympathetic neighboring farmers who agreed to care for their crops. With the assistance of near-by farmers, Etsuo received a percentage of the income from the crops on his owned property. ${ }^{137}$ Some, not as fortunate as Etsuo, struggled to find caretakers in the decreased labor force left in the

\footnotetext{
134 Ibid., 329-330.

135 "Jap Exodus Starts Here Wednesday," 1.

${ }^{136}$ Sandra C. Taylor, "Evacuation and Economic Loss: Questions and Perspectives," in Japanese Americans: From Relocation to Redress, ed. Roger Daniels, Sandra Taylor and Harry Kitano (Seattle: University of Washington Press, 1991), 163.

137 Namba.
} 
wake of military conscription and wartime industries. These farmers shared the fears of the federal government: that their produce would not be cared for during their absence. While the evacuated farmers dreaded the notion that they would lose their income and investment for the year, the government worried that the increased war-time demands for fruits and vegetables could not be met without the produce from Japanese farms. In Oregon, the Japanese population owned and operated farms responsible for $\$ 4$ million of produce annually. ${ }^{138}$ In the Portland area, Japanese farms produced ninety per cent of the brussel sprouts, green broccoli, and cauliflower; seventy-five per cent of the celery; more than half of the lettuce, green peas, and spinach; half of the eggplants, tomatoes, and green peppers; and nearly half of the carrots, cabbage, and green beans. Citing these statistics, Ray W. Gill, chairperson for the victory war gardens committee in Portland, warned the community of the extra burden that awaited family gardens and other growers. ${ }^{139}$

In March 1942 the Farm Security Administration (FSA) became responsible for ensuring that farms owned or run by Japanese would continue to be productive during their internment. Over six thousand Japanese-operated farms needed to be transferred to new operators without disrupting agricultural production. The agency attempted to reduce manpower needs and increase economic efficiency by consolidating several of the Japanese farms. ${ }^{140}$ However, the FSA did not maintain control of the property for long, and by May 1942 the wartime civil control administration attempted to dispose of Japanese farms. The agency had sold or leased eighty-five per cent of the acreage that 
once belonged to the internees and offered enticements of special loans, assistance in planning future crops, and help in obtaining credit to encourage farmers to purchase or lease the remaining 36,000 acres. ${ }^{141}$ This system allowed Japanese produce to be harvested, but Japanese farmers suffered immensely, while the new white operators recorded tremendous gains. Operators who agreed to manage Japanese homesteads were at a strategic advantage because the FSA desperately needed them to operate the farms and wartime demand assured high profits. Therefore, they could negotiate immunity from financial risks caused by bad weather or pests and receive ample loans from government corporations. "The fruit companies [who operated Japanese farms in this manner] obtained generous, risk-free government loans to subsidize their operation (loans were secured on the assets of the Japanese farms), acquired the full use of the farm machinery on those farms at no cost, and, in most cases, shared half of the profits on the sale of the 1942 crops," Okihiro and Drummond wrote. Therefore, operators gained large profits for minimal work and accepted no risk. This program also worked to the operators' advantage because it offered no reason to maximize profits or recover any of the cash advances made to the farms, since the loans used Japanese property as assets. Additional corruption occurred because the farm profits were traditionally shared equally with the farmer and the packing plant or food processor. However, now that the corporations controlled both aspects of production, there was no incentive to realize a profit for the farms, still owned by Japanese. Costs were thus artificially inflated and charged to the Japanese farm owners, showing little or no gain on paper. Profits were 
recorded as made only on the packing and processing sector of the corporation, and the interned Japanese farmers received little or no income for their annual harvest. ${ }^{142}$

The following season, farmers who had leased Japanese land in spring of 1942 demanded the same no-risk arrangement. The government refused to grant the loans and the FSA could not offer the same advantages as the previous season. Therefore, most of the corporations refused to lease Japanese farms in the fall of 1942. Japanese farmers, who were being moved from assembly centers to internment camps throughout the United States, were powerless. Without anyone to plant and care for their crops, many Japanese farmers were forced to foreclose on their farms. ${ }^{143}$

Evacuees not only suffered financial setbacks, but they felt the sting of antiJapanese sentiment during the war. While people east of the Rockies hated the Japanese who bombed Pearl Harbor, people along the West Coast directed their abhorrence at the Japanese who once lived among them. Evacuation proved what they had been insinuating from the turn of the century: that Japanese were a danger in their midst. Furthermore, once Japanese, who had been neighbors, customers, tenants, or otherwise engaged in business, no longer comprised a customer base, criticism of the Japanese became more biting. Efforts by agricultural competitors and politicians echoed the debates a generation earlier, attempting once again to keep Japanese residents out of the West Coast states. 


\section{6: Welcome Home, the 1945 Alien Land Law}

"[A]fter the evacuation had been effected, the nation noted, rather to its amazement, that agitation against persons of Japanese ancestry on the West Coast noticeably increased....Agitation on the West Coast for removal of the Japanese was nothing compared to the agitation that developed, after their removal, to prevent their return," Carey McWilliams wrote in $1945 .{ }^{144}$ Many of the same arguments arose from twenty years earlier, such as the notion that Nikkei could not be assimilated and that they threatened to take over agricultural land along the West Coast. Some of the same people also reappeared, including Oregon's former governor Walter Pierce, who addressed Congress. Urging citizens to "learn to grow our own vegetables and to pick up potatoes for ourselves," the former governor asked Congress to "cut them out, root and branch," sending all Japanese residents back to their native island country. ${ }^{145}$ Because Congress would not deport people of Japanese descent, state legislatures began debating laws that would prevent Japanese from relocating there.

The most effective of these laws were the alien land laws. Across the nation, state legislatures debated laws that would restrict people of Japanese descent from owning or even leasing land. Fearful that residents of the internment camps of Rohwer and 
Jerome, Arkansas might choose to remain after the war, the legislature passed a law stating that "no Japanese or a descendant of a Japanese shall ever purchase or hold title to any lands in the State of Atkansas." Utah and Wyoming also passed laws restricting land ownership by Japanese, and California revised its earlier alien land law to make it more restrictive. $^{146}$

In Oregon farmers led the attempt to reinvigorate alien land law legislation. In its annual meeting in 1943, the State Grange focused on the threat of returning Japanese internees. State Grange Master Morton Tompkins claimed that Japanese farmers forced white farmers out of business "and into hiring themselves to the Japanese landlords. At the beginning of this war," asserted Tompkins, "the Japanese owned or controlled vast acreages of the richest farm lands....Steps must be taken at the opportune time to see that it is stopped." ${ }^{147}$ After the war farmers in Hood River had even greater financial incentives to fight the return of Japanese to their community. Agricultural land there sold for approximately $\$ 200$ or $\$ 300$ per acre for much of the first half of the century. After the war, however, the price of land there increased ten-fold. Furthermore, total farm income soared in Oregon during the war years, increasing by more than forty per cent. (See Table 5.) Considering the economic situation, grange organizations in five western states favored amending the Constitution so that children of aliens would not be granted citizenship by birth right, in an attempt to prevent Japanese farmers from avoiding the land laws by purchasing property in the name of their children. Additional attempts to diminish competition included a Grange resolution against permitting any Japanese to 
relocate in the West Coast states. Although no one group was held responsible,

economic coercion was used by anti-Japanese farmers who approached produce buyers and threatened retaliation if they purchased from Japanese. In addition, processors of fruits and vegetables refused to allow Japanese farmers to use their facilities. Fear that other farmers would boycott the buyers and processors forced the companies that may have been sympathetic to Japanese farmers to act against them. ${ }^{148}$

Table 5: Oregon Farm Income ${ }^{149}$

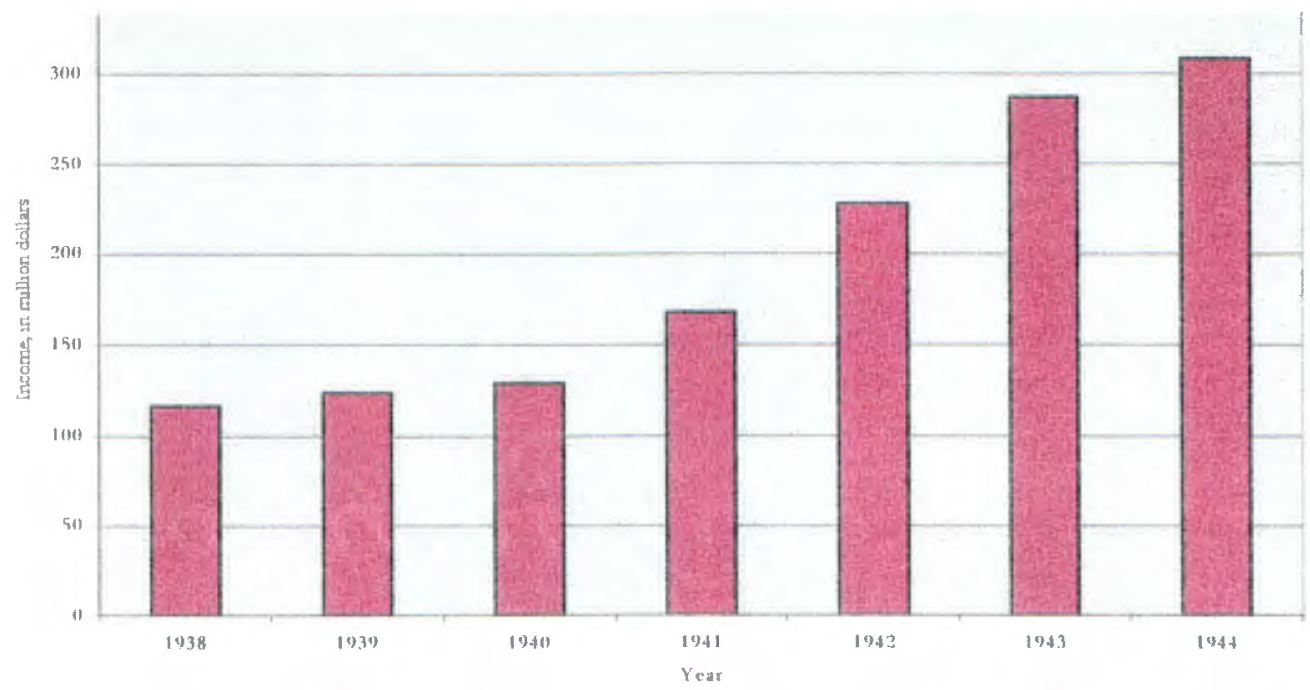

The mayor of Hood River, Joe Meyer, supported the farmer's position: "Ninety per cent [of the people of Hood River] are against the Japs!-Why? Well, because we trusted them so completely while they were here among us, while all the time they were plotting our defeat and downfall.... They were just waiting to stab us in the back." In In Hood River, the American Legion reasserted its leadership of the anti-Japanese

\footnotetext{
147 "Grange View on Japanese Problem," Hlood River News 18 June 1943, p. 8.

14H Pursinger, 409. Iwata, 519. "The Victims of Expediency," Ilood River News 22 December 1944, p. 8. "Farm income," 10. "Japanese Exclusion League is Aggressive," Oregon Voter 105 (18 August 1945), 11. 1.49 "Farm Income," 10.
} 
movement, removing the names of sixteen Japanese-American soldiers from their honor roll in December 1944. In "A Statement on the Japanese" published shortly after the war, the Hood River Legion accused the Japanese and their descendants of a plot to take over property in the United States. Arguing for the need for a more restrictive alien land law, the Legion contended that the Japanese had devised methods of evading the 1923 alien land law by buying property in the names of their United States-born children. "By almost annual child-bearing the 'picture brides' furnished a broad highway to the ownership of the best lands on the West Coast." A lawful solution to the Japanese problem consisted of investigating all property title transfers to Japanese that occurred after 1923, the prevention of further sales to Japanese, and the formation of a committee that would purchase all remaining Japanese-owned property. To illustrate the animosity present in Hood River, the Legion proposed holding an election to poll residents on their opinion on Japanese returning to their community. ${ }^{151}$

In 1944 anti-Japanese forces organized the Hood River Citizens Committee, incorporated to preserve the spirit of Americanism by fostering understanding and betterment of the citizens of the valley. ${ }^{152}$ Also in Hood River, Kent Shoemaker, an American Legion member, organized his own campaign against the return of Japanese residents. In a series of full-page advertisements in the Hood River News, Shoemaker presented his objections to Japanese residents, including their inability to assimilate, their dual citizenship, and their threat to national security. "Let us keep Japan for the Japs and

\footnotetext{
${ }^{150}$ Beatrice Stevens, "Free and Equal? The Japanese-Americans in Oregon," Portland: A unit of work for secondary schools prepared for the workshop on intercultural education, 1945, 35. 151 'Nisei Soldiers' Names Erased By Local Legion," Hood River News 8 December 1944, p. 1. Hood River American Legion Post No. 22, "A Statement on the Japanese," (Otegon Historical Society, Portland, Microfilm.) "Legion For Exclusion Of Japanese," Hood River News 8 December 1944, p. 1. "Iegion May Plan Special Election," Hood River News 12 January 1945, p. 1.
} 
Hood River for our own prosperity," he urged readers. His intimidation tactics attempted to force Japanese residents to sell their land, thereby establishing racial exclusion regardless of the legal rights of Nikkei to own property. Under his advertisements, he listed almost two hundred names of community members who supported his battle. ${ }^{153}$

An organization similar to the Citizens Committee of Hood River, the Oregon Property Owner's Protective League, which boasted a membership of 1500 people in 1945, sought to educate the public about aliens residing in the state. The backgtound, history, pre-war activities, and future disposition of foreign-born residents all were listed as important highlights of the Gresham-based group's educational program. While the Oregon Property Owner's Protective League had a short life, being dissolved in January of 1948, its activities in those three years impacted the Japanese who attempted to resettle in their communities. ${ }^{154}$

Large advertisements in the Gresham Outlook invited people to join open meetings free of charge. "How Will We Rid The Coast of the Japs?" one headline asked. Among the presenters at one Gresham session was a spokesman from the Hood River Post American Legion, "whose anti-Jap fight has attained national prominence." 155 Another ad proclaimed that the League intended to "Keep Japs off the Pacific coast for the duration, deport all aliens and disloyal Japs, [and to] submit the problem of American-

\footnotetext{
152 Multnomah Bar Association, "The Japanese Problem in Oregon," Oregon Law Review 24 (1944-45), 215.

153 "Keep Every Jap Out of Hood River Valley," Onegon Voter 105 (17 February 1945), 16, 17. Kent Shoemaker, (advertisement) Hood River News 23 February 1945, p. 6 and 26 January 1945, p. 10. 154 Pursinger, 448.

155 "How Will We Rid the Coast of the Japs?" (advertisement) Gresham Outlook 8 March 1945, p. 5. The Hood River Post of the American Legion received more notoriety than prominence when it removed the names of seventeen Japanese-American soldiers from the honor roll of those killed in service. The National office of the American Legion responded by denouncing the Hood River post for its action.
} 
born Japs and those Japs who fought in our army, to the voters..." "The cost is little," the ad reminded readers, "a mighty small amount for your share in a fight that means so much to you!" 156

The Gresham Outlook reported that nearly one thousand people attended one meeting of the Oregon Property Owner's Protective League in February 1945. Oregon Governor Earl Snell and former Governor and United States Representative Walter Pierce informed the audience about the need to change state laws and the U.S.

Constitution. Snell demanded that no person of Japanese descent be allowed to return to Oregon prior to the end of the war with Japan. He also suggested that Congress pass a Constitutional amendment so that no person of Japanese descent be permitted to become a citizen, regardless of place of birth. Pierce suggested that Japanese descendents with U. S. citizenship were part of a plan of the Japanese Empire to dominate the United States and the world. Criticizing Oregon for its inaction to date, Pierce urged all present to bombard their state legislators with demands that they implement these changes to the Constitution. Several neighboring communities inquired about forming branches of the Oregon Property Owners' Protective Association. ${ }^{157}$

The following month an attomey from Seattle addressed the group. Pointing to high birth rates among the Japanese and accusing them of treachery and deceit, he

156 "The Time to Join is Now," (advertisement) Gresham Outbok 15 March 1945, p. 5. 157 "Enforcement of Land Laws is Demanded," The Gresham Outlook, 15 February 1945, p. 1. Next to this article was a smaller article titled, "Two Jap Families Back to Farms Here." The article took a nonprejudiced stance, simply reporting the fact that two families had returned from evacuation, stating that in their absence they had continued in agriculture. The article concluded with the fact that two sons of one of the families were currently serving in the United States Army, one of them on front line duty in France. Pierce cited the fact that Japanese-Americans were afforded dual-citizenship by Japan, thus making them loyal to the enemy nation. "Group Asks Ban Be Put On Nippons," Oregonian 10 February 1945, p. 1. Pierce cited the example of Washington's three lawsuits that were attempting to confiscate land from Japanese residents. "Pierce Slaps at Japanese," Oregonian 10 February 1945, p. 4. 
repeated the charge that "The only good Jap is a dead Jap."158 The lawyer called for the deportation of all people of Japanese descent and a federal law that would prohibit anyone from Japan from entering the United States "for all time."159 At the same meeting Oregon state representative Warren Erwin, a Democrat from Portland, suggested that the legislature adopt a memorial advocating the permanent exclusion of Japanese, warning that guerrilla warfare could ensue if the Japanese were not removed. ${ }^{160}$ Former Marine $T$. W. Pattee recalled the brutality and treachery of Japanese warfare that convinced him that Japanese were not fit to be residents of the United States. ${ }^{161}$

Many of the same founders of Oregon Property Owner's Protective League also organized an aggressive group originally named the Oregon Anti-Japanese, Incorporated. Upon the suggestion of the attorney general, the members agreed upon a less discriminatory name, calling themselves the Japanese Exclusion League. This Greshambased organization proposed to prevent the return of Japanese residents during the war and to promote legislation that would exclude all Issei, Nisei, and Sansei (third generation Americans) from citizenship. ${ }^{162}$

In response to the anti-Japanese movement, important leaders of the Oregon clergy and political establishment organized to present a pluralist vision of the state's future. "I am serving as chairman at the request of a sizable group of residents of this area who are desirous of having 'the other side' of this question told publicly," local minister and American Legion member John L. Magoon told the Gresbam Outlook in

\footnotetext{
158 Stevens, 34.

159 "Start Drive to Get Funds for Campaign," The Gresham Outlook, 15 March 1945, p. 10.

160 Stevens, 34.

161 "Start Drive to Get Funds for Campaign," p. 10. Pattee's loss of his left arm in battle was mentioned in the article and most likely aided his argument.

162 Multnomah Bar Association, 215-16.
} 
February $1945 .{ }^{163}$ One day after their opponents' meeting at Gresham High School, approximately one-thousand people attended a counter demonstration to hear former Governor Charles Sprague and prominent Portland banker E.B. MacNaughton share the "correct information" on "the inalienable rights of all Americans, irrespective of ancestry or extraction." Sprague argued that actions to prevent the Japanese from returning would be futile and pointed out that all people of Japanese descent had been thoroughly screened prior to their release. Furthermore, it was the Army that permitted their return, and Army actions were above the pale of civilian action. Sprague also quieted concerns that the Japanese population was exploding in an attempt to take over the world. Quoting census statistics, the former governor reported that the population of people of Japanese descent in the United States had decreased in the previous decade. Sprague further stated that the Japanese were a peaceful people. He only had agreed to wartime evacuation because it was an army issued order, he insisted. "Up to that time and since then," Sprague said, "I know of not one single act of sabotage or traitorism committed or on record as having been committed by any person of Japanese extraction in the state of Oregon." MacNaughton warned the audience not to use the Japanese as a scapegoat for the war, nor any other group, such as Jews, Catholics, African-Americans, or even bankers. "Anything can happen when the fires of prejudice are whipped up and men forget the promises by which our lives are ordered," cautioned MacNaughton. ${ }^{164}$

Community members in Hood River also came to the defense of Japanese residents. One women asked teaders of the local newspaper, "While these DapaneseAmerican] boys are fighting our battles, is it right to take away their citizenship, their 
farms and break up their homes?" The newspaper itself offered its suppott by printing such letters as well as in its comments. "If one is honest," one reporter reminded readers, "it must not be overlooked that, outside of those orchards which Japanese themselves developed, and in a number of instances from stump and brush land, their holdings as of two years ago, were acquired by purchase, simply because American owners were willing to sell at a price with which they, themselves, were well satisfied."165

Nationally, the American Legion showed their support of Japanese-American soldiers by welcoming the sixteen soldiers whose names had been removed from the honor roll as members of another post. Several letters to the editor criticized the Legion's undemocratic actions. A month after the names were removed, the National Commander of the Legion reprimanded the Hood River Post for the embarrassment they brought upon the organization. "The American Legion has always maintained that bigotry and race hatred have no place in American life," stated the Commander, "and the action of this one individual post... was ill considered and ill advised and contrary to the ideal and purposes for which the American Legion is organized." His request that the names be reinstated was granted in March $1945^{166}$

Paralleling the debates that occurred throughout Oregon communities were the deliberations of the Salem legislature. Representative Vernon Bull (D- La Grande) presented House Joint Memorial 7 that would provide for deporting certain Japanese. The bill died in committee. Two weeks later, at the urging of Walter Pierce, he attempted 
to pass a bill that would exclude Japanese from the Pacific Coast for the "duration."

That too died in committee. Following the house's failure to move on restriction, the state senate considered a proposal to "regulate further the rights, powers and disabilities of aliens to own property in this state." The powerful agricultural interests in Oregon enabled Senate Bill 274 to pass unanimously with little debate. Approved in the House by 53-2, the Governor signed it into effect in March. By forbidding any alien ineligible for citizenship to even set foot on farmland, the law filled the loopholes that permitted Japanese residents to purchase land in the name of their American-born children and work under the guise of a sharecropping contract. Penalties for violating the law included up to two years in the state penitentiary or a fine of up to $\$ 5,000$ or both. ${ }^{167}$

Nearly one year after the enactment of the revised Oregon alien land act, all U.S. government internment camps had been closed and their inmates permitted to return to their homes. Until August 1945 the War Relocation Authority had attempted to serve the returning Japanese though its relocation assistance offices. Working to make the transition as peaceful as possible, the WRA sent supervisors to Hood River and other communities to explain that the Japanese had the right to reside wherever they chose, but added that they were urging internees to relocate to homes in the Midwest or East. For those who opted to return to their hometowns in Oregon, the WRA sought to assist the landowners in their dealings with those who had leased their lands during the war. When tenants refused to pay due taxes, for example, the agency confirmed that it was the

March 1945, p.1. The Legion added that replacing the names did not signify a change in their position towards Japanese residents of Hood River.

167 "Japanese Exclusion," Ongon Voter 105 (April 14, 1945), 18. The law broadly defined the "owner" of agricultural land to be anyone who would "remain or go upon the land, farm and cultivate the same and enjoy directly or indirectly the beneficial use of such agricultural lands or... a beneficial interest in or use of 
tenant's responsibility to do so and advised owners to turn the matter over to an

attorney. The WRA also acted as the middle person between the Japanese landowners

and tenants who owed rent. ${ }^{168}$

Government agencies were as concerned about enforcing the new laws as they

were about protecting the rights of Japanese-Americans. While Ray Yasui was granted

early release because of his American citizenship, his Hood River property was restored

to him only after the Department of Justice warned that his father would not be

permitted on the land, since all Issei still were considered enemy aliens. ${ }^{169}$ In California,

the state legislature appropriated $\$ 200,000$ for the vigorous enforcement of alien land

laws. ${ }^{170}$

Religious leaders, educators, and civil rights activists organized the Portland

Citizen Committee in February of 1945 to assist Nikkei in the difficult transition. Labor

organizations, such as the Oregon Congress of Industrial Organizations, also pledged

the proceeds received from the sale of the agricultural crops produced on said lands" Oregon Laws, 1945, Chapter 436.

168 "Army Ends Exclusion of Japanese," Hood River Nens 22 December 1944, p. 1. "WRA Part in Jap Problem in Explained," Hood River News 9 march 1945, p. 1. Yasui Collection, MSS 2949, Box 3 and 9 , Otegon Historical Society, Portland.

${ }^{169}$ Carl C. Donaugh, Portland, to Ray L. Yasui, 30 July 1945, Yasui Collection, MSS 2949, Oregon

Historical Society, Portland.

170 Bill Hosokawa, Nisei: The Quaiet Americans (New York: William Morrow and Company, 1969), 447-448.

With the reinstated funds, enforcement of laws resulted in eighty new escheat cases, court challenges in which the title to the property would be given to the state if the defendant were found guilty of violating the laws. Several cases were filed against Nisei who held land, arguing that the land was purchased in their name merely to circumvent the law. These escheat actions threatened to take a heavy toll on Japanese returning from evacuation. Many Japanese, struggling to keep the land that they purchased and were fortunate enough to hold onto during their evacuation, sought to settle the actions rather than risk loss of property in a court hearing. Of the nineteen escheat cases decided in California prior to repeal of the laws, only seven resulted in the property being escheated to the state. The state then sold this property, bringing in $\$ 57,864$. The remaining twelve cases were settled with a compromise, in which the defendants paid half of the appraised value of their land so that the state would drop the case. As a result of these compromises, the state of California took in $\$ 231,915$. As historian Bill Hosokawa stated, the escheat actions in California "amounted to no more than blackmail." 
their support of the returning internees. ${ }^{171}$ In Hood River, Mrs. Max Moore helped establish the Hood River County League for Liberty and Justice, a group that attempted to launch a counterattack on anti-Japanese propaganda with educational programs in intercultural relations. ${ }^{172}$

Despite attempts to promote better relations with the Japanese, returnees often faced a hostile reception. Some found their houses defaced. Others were threatened with bodily harm, and still others found themselves involved in court actions to escheat their property. Etsuo Namba returned to Gresham to find that his pickup, tractor, and other vehicles and farm implements that he had stored in his barn had been stolen. Like most returning Japanese, he discovered that amid wartime restrictions on the production of farm implements and equipment, Japanese property was coveted. Although much of the stolen equipment was registered to Etsuo, such as the truck and tractor, reporting the incident to the police produced no results. To aggravate matters, the wartime owners of Etsuo's land refused to allow him to resume farming the large tract of land he had leased. He was forced to start over again, with nothing. Etsuo's son, Kennie, remembered returning home with his new bride, stepping into a grocery store in his U.S. Army uniform, and being refused service. "We fought the war [in Europe] and then we had to fight our own war when we came back, the discriminatory segment of it," he recalled. ${ }^{173}$ "We met [a] certain amount of animosity, [a] certain amount of discrimination," recalled another Gresham returnee, Jack Ouchida. "We had to pay cash for everything. Some outfit will not sell [to] you...[S]ome organizations or constitutions said 'white only."” 
Jack noted that in small towns, such as Gresham and Hood River, discrimination was much more prevalent than in Portland. ${ }^{174}$

Ray Yasui attempted to resettle in his hometown of Hood River, but found the animosity directed against himself and his family too harsh. He began looking for agricultural land in Idaho. However, he struggled to gain property because he was unable to earn much money while he was interned. "As you can readily understand," he wrote to one person selling land in Idaho, "my income has been limited since the time of evacuation, and therefore [I] would not be able to give you a monetary payment of any amount as down payment. However, if hard work and ambition pays off to any extent, I believe that I will be able to qualify, and could insure you that I have but the best intentions in mind."175

Those fortunate enough to still have property in their name sometimes found it difficult to regain control of it. Masayuki Fujimoto, a farmer from Boring, returned to find that the couple to whom he had leased his farm during interment refused to leave the farm. The case went to the Clackamas County circuit court in March of 1945. The jury's decision awarded Mr. Fujimoto the immediate return of his property. The tenants vowed to appeal the decision, stating that they would "sit tight" until the final disposition by the highest courts was made. ${ }^{176}$

Most Japanese residents avoided these situations by moving to states further east after the war. In Hood River the newspaper speculated that only one-third of the former

\footnotetext{
174 Jack Ouchida, Interview by Linda Doami, 8 April 1995, Inv. 969, transcript, Oregon Historical Society, Portland, 11.

175 Ray Yasui to Mr. M. C. Hinshaw, 19 January 1945, Yasui Collection, MSS 2949, Oregon Historical Society, Portland.

176 "Farmer Ouster Asked by Jap," The Gresham Outbok 1 March 1945, p. 1. And "Court Grants Bergh

Ouster," The Gresham Outlook 8 March 1945, p. 1.
} 
Japanese residents would return. The War Relocation Authority urged released internees to avoid the West Coast states, and high land prices further discouraged Japanese farmers from returning. The United States Department of Agriculture did not expect more than 22 to 33 per cent of the West Coast Japanese population to return. ${ }^{177}$

Anti-Japanese agitation, aroused by farmers and Grange Associations, resulted in the 1945 land laws that prevented Issei farmers from living in Oregon. The harsh environment created by organizations such as the American Legion, the Hood River Citizens Committee, the Oregon Property Owner's Protective League, and the Japanese Exclusion League discouraged many Japanese, both Issei and Nisei, from returning to Oregon after internment. Still, there were several individuals and groups, such as that headed by John Magoon, who supported their former neighbors and attempted to make the transition home easier for Japanese residents. These groups, coupled with the efforts of the small Japanese community that returned to Oregon, were able to challenge and overcome the anti-Japanese sentiment and legislation.

177 "Three Nisei Return to Valley Homes," Hood River News 19 January 1945, p. 4. "USDA Gives Data on Jap Farm Holdings," Hood River News 9 March 1945, p. 10. High land prices were especially devastating to Japanese farmers because seventy per cent of those who were involved in agriculture leased their land prior to the war, and thus would be forced to enter new leases or purchase land upon their return. 


\section{7: Namba v. McCourt: The Land Laws Repealed}

Those Japanese who returned to their Oregon homes wasted little time in organizing against the discriminatory legislation. The Committee for Oregon Alien Land Law Test Case formed in 1946 with Issei leader Daiichi Takeoka as chair. Takeoka had a long history of serving the Japanese community in the Portland area. After receiving his law degree from the University of Oregon, he served as legal and financial counsel to many in the Japanese community. He also acted as a liaison between whites and Nikkei. ${ }^{178}$ The Multnomah Bar Association had already begun researching the situation of Japanese residents in Oregon, paying special attention to how the wat affected the rights of resident aliens, the anti-Japanese sentiment, and the revised alien land laws. After a discussion on the laws and legal rights of Japanese in Oregon, the committee investigated the reasons for anti-Japanese sentiment after the war, finding that "they seem to have been initiated, guided, and directed by persons and groups who were chiefly motivated by hope of economic aggrandizement." In an attempt to provide a factual report, the committee failed to make any moral evaluations or recommendations to the bar association. However, Verne Dusenbery, the bat's president, was not satisfied with status as an alien ineligible for citizenship. Barbara Yasui, 253. 
the limitations of those efforts. After soliciting the services of recent Yale University

Law school graduate and war veteran Allan Hart, the two offered their services to

Takeoka and the Japanese committee. ${ }^{179}$

Dusenbery's and Hart's first obstacle was to create a test case that they could

bring before the court. "We needed to put together what would look like a case of

controversy... what seem[ed] to be a real dispute," Hart said in an interview. ${ }^{180}$ Central to that dispute was finding land that Japanese residents could purchase or lease in violation of the laws. Hart and Dusenbery looked to the wife of a fellow attorney from La Grande, Florence Donald, who agreed to lease the strawberry fields she owned near Gresham to aliens ineligible to citizenship. With the help of the Japanese American Citizens League (JACL), Hart chose an Issei father and Nisei son, Etsuo and Kennie Namba, to serve as the tenants and constructed an appropriate lease. When Kennie and Etsuo agreed to represent the Japanese community, Hart saw the case come together. "Etsuo Namba and Kennie Namba were made to order for us, for our needs," Hart said.

In 1946 the Namba family was returning to their Gresham home after several years in the Minidoka internment camp. Etsuo Namba had settled in the Gresham area in 1917 and began farming strawberries and vegetables. When the evacuation orders came to Multnomah County, he and his wife Shizuno packed up their five children and left their farm. Neighbors agreed to care for the small parcel of property that Etsuo owned. The owner of the larger portion of land that Etsuo was leasing found someone

179 Multnomah Bar Association, 208+. "Japanese Exclusion League is Aggressive," Oregon Voter 105 (18 August 1945), 6. Allan Hart, interview by James Strassmaier, 10 June 1986, Tape Recording, Oregon Historical Society, Portland. Hart's interest in civil rights was so strong that when he filled out the application for the American Bar Association he refused to answer the question about race as a statement about the Association's policies prohibiting blacks from joining.

${ }^{180} \mathrm{Hart}$. 
else to care for the property during Etsuo's internment. Kennie chose to leave Minidoka early to serve in the highly decorated $442^{\text {nd }}$ Infantry Regiment in Italy. In February 1946 he received an honorable discharge and returned to Gresham to reunite with his family and his new bride, Ruth. ${ }^{181}$

Etsuo and Kennie agreed to challenge the laws that prevented Etsuo from pursuing his livelihood. On their frequent visits to Hart's office, the Nambas learned about the lease of Donald's sixty-two acres for a period of five years with Etsuo and his son Kennie each holding a separate contract for thirty-one acres. For one contract to be valid, both had to be executed. The house was to be situated on Kennie's half of the property, where Etsuo and Shizuno were to live with Kennie and his young wife. Being an experienced farmer, Etsuo would assist and advise his son for the first two years while also cultivating his own acres. Such a contract violated both the 1923 and 1945 alien land laws; Etsuo's lease violated the 1923 measure; his residence with and assistance to Kennie violated the 1945 provisions.

In putting their case together, Dusenbery and Hart were forced to respond to several precedents. In Ozawa v. U.S. (1922) the U.S. Supreme Court had ruled that the framers of the constitution did not consider people of Japanese descent free white persons. Therefore, Japanese were not eligible for citizenship and the alien land laws could be enforced. ${ }^{182}$ The following year the Court upheld the alien land laws in Washington as a privilege of the state police power. ${ }^{183}$ The tribunal also sustained California's alien land laws, making a particular point to approve of the prohibition of

181 Namba.

182 Chuman, 70-71. 
cropping contracts between citizens ineligible for citizenship and citizen farmers. ${ }^{184}$ In a fourth case in 1923 the Court decided that although aliens had the right to engage in commerce, that did not necessarily mean they had the right to acquire shares of stock in companies that could purchase agricultural land. ${ }^{185}$ In 1924 the Supreme Court once again upheld the California laws by concluding that aliens ineligible for citizenship could not control or benefit from agricultural lands, even if they were held in a citizen's name. ${ }^{186}$ Although the precedents did not favor Dusenbery and Hart, they firmly believed that they could change the laws with their case. ${ }^{187}$

With the elements of the case in place, the only missing link involved the pressing of charges by Multnomah County. District Attorney John McCourt, a colleague of Hart, agreed to participate, even at the political risk the collision involved. ${ }^{188}$ When the case came before county Judge James W. Crawford in April 1947, the defense advanced twenty reasons why the prosecution of their clients was unconstitutional. First, the law violated the Fourteenth Amendment to the United States Constitution as well Article I, sections 18 and 20 of the Oregon State Constitution. By depriving Donald of her rights to dispose of her property and enter the contract, her substantive due process rights had been violated. Moreover, Kennie Namba, a United States citizen, was also deprived of property without due process of law since he could not enter into the lease without his

${ }_{183}$ In Terrace $v$. Thompson, the justices ruled that without such laws, the entire state was in danger of ownership by aliens.

${ }^{184}$ In Webb v. O'Brien, the justices found that any length of lease still provided the tenant with the right to use and benefit from the land, in violation of the legislation. Konvitz, 163.

${ }_{185}$ In Frick v. Webb, the challenge involved an alien's membership in a corporation that owned agricultural land.

186 At issue in Cockrill v. California was whether parent residents could gift land to their citizen children.

Konvitz, 163.

187 Namba.

${ }^{188}$ Hart. 
father accepting the other half. In addition, the alien land law deprived Kennie from the right to live with and work with his father and "restricts him in maintaining his father... and his mother...should they become poor and unable to work." These limitations were imposed on Kennie solely because of racial discrimination, the complaint stated. Similarly, Etsuo was denied due process of law by not being permitted to reside with or work with his son. The Fourteenth Amendment guaranteed the right to earn a livelihood to anyone residing in the nation, whether he or she was a citizen or not. ${ }^{189}$ Judge Crawford ruled that the intention of Section 1 of Chapter 436 of the Oregon Laws of 1945 was to prevent evasion and subterfuge by ineligible aliens and that such provisions of the law were valid, constitutional, and enforceable. However, he declared that the negotiated lease between Florence Donald and Kennie Namba, who were both citizens, did not appear to be made in bad faith nor "as a trick or artifice for the violation of the law." Therefore, the parties had entered the contract without violating the laws. The decree found four sections of the law invalid. For example, proof of citizenship by voter registration was not considered a satisfactory test of citizenship. Furthermore, the assumption could not be made that simply because one tilled or occupied the land, that he or she was the owner or leaseholder. Yet Crawford ruled that if Etsuo entered into a contract with Donald, they would be subject to penalties of fines and escheat, as stated in the law. ${ }^{190}$

While Hart and Dusenbery were working on the appeal, the Supreme Court ruled in Oyama v. Califormia (1946) that it was legal for a Japanese alien ineligible for citizenship

\footnotetext{
${ }^{189}$ Circuit Court of the State of Oregon for the County of Multnomah, Complaint, 6.

190 "Judge Declares Japanese May Live on Leased Land," Sunday Oregonian, 12 October 1947, p. 18. James

W. Crawford, "Decree No. 175-930," 12 November 1947.
} 
to purchase land in trust for his U. S. born son, although the justices failed to find the California land laws unconstitutional. "It was a timid approach to the recognition that those 1923 cases were outrageous," Hart criticized. Using the Oyama case when the Namba case appeared before the Oregon Supreme Court in March of 1949, Hart asserted that the circuit court had erred when it declared the Oregon alien land laws constitutional. "The most significant and important change in the relevant facts since 1923 has been the substantial decrease in the number of ineligible aliens residing in the principal states having alien land laws," his brief stated. ${ }^{191}$ The brief also cited legal changes in the field of constitutional doctrine. "This development has brought a fuller understanding of the liberties guaranteed by the Constitution to all persons, and of the closeness with which abridgements of these liberties must be scrutinized by the courts," the appellants argued. ${ }^{192}$ The Oyama case exemplified this line of argument, as the appellants recalled that not one of the nine Supreme Court Justices viewed the 1923 rulings as controlling in contemporary decisions. "As a matter of fact," the brief caustically stated,

the effort to discover a reasonable and legitimate basis for this classification is bound to fail, because the truth is that the Alien Land Law was conceived only in the spirit of racial prejudice, and it has only a single purpose throughout its entire history: to harass Japanese aliens and to discourage them from residing within the state. $^{193}$

Dusenbery and Hart once again argued that Oregon's 1945 land act violated the state constitution's equal protection and due process statutes as well as the Fourteenth Amendment. The attorneys also criticized the law for violating the 1911 treaty with Japan by denying a legal resident the normal means of making a livelihood. The respondent's

${ }^{191}$ Appellant's Brief, October term, 1947, Oregon State Archives, File No. 10014, 23. The brief recorded that only 900 ineligible aliens resided in Oregon in 1948, a number too small, and mostly elderly, to be considered a threat to national security. (50) 
brief, argued by Deputy Attorney General Rex Kimmel in March 1948, declared that the Supreme Court recognized the laws as a valid exercise of state police power and cited the precedents of alien land law cases in California and Washington. "It was not the acquirement of title in fee alone that this legislation was designed to prevent," the state argued, "It was intended to withhold from ineligible aliens all of the advantages of ownership of agricultural land gives. It was intended to withhold from them dominion, occupancy, possession, enjoyment...It was intended to free the American farmer from the competition upon American soil, of the Oriental farmer." 194

In response to the argument that the 1923 law was outdated, Kimmel stated that it was the responsibility of the state legislature to address such issues, not the judicial system. The notion that the laws discriminated on the basis of race was refuted by the fact that aliens ineligible for citizenship were not permitted to acquire property in the District of Columbia or in territories belonging to the United States. Moreover, Japanese were not, Kimmel argued, the only race ineligible for citizenship. Afghans, Burmese, and Polynesians were all mentioned as races also ineligible, although none had a population within Oregon at the time. Finally, the respondents declared that in a democracy the rights of the public took priority to the rights of individuals. "It is an axiom of our society that the rights of an individual, where they come in conflict with the public welfare, must give way to the rights of the public," the state brief read. ${ }^{195}$

After listening to the arguments, Chief Justice Hall S. Lusk prepared to deliver the court's opinion. A Roman Catholic, Lusk had successfully challenged the Oregon 
compulsory school bill of 1923. Lusk now decreed that the alien land laws violated the Oregon Constitution and the Fourteenth Amendment and declared the laws void. "It is therefore considered, ordered and decreed that the appellants are entitled to a decree as prayed for in their complaint declaring the Alien Land Law violative of the principles of law which protect from classification based upon color, race and creed," his opinion read. ${ }^{196}$ "Our country cannot afford to create, by legislation or judicial construction, a ghetto for our ineligible aliens. And yet if we deny to the alien who is lawfully here the normal means whereby he earns his livelihood, we thereby assign him to a lowered standard of living. We know of no basis upon which these two acts can be sustained."197 Just after the Court reached its decision, the Oregon legislature repealed the state alien land acts in April 1949. ${ }^{198}$ Other states followed Oregon's example. In California, the JACL lead a successful campaign against a 1946 ballot measure seeking to legitimize revisions to the state alien land act that were legislated in the 1940s. Mike Masaoka, prominent JACL leader and war veteran, declared, "The election results prove that most Californians feel that Japanese Americans and their Issei parents have earned the right to justice and fair treatment." ${ }^{\text {199 }}$ Six years later, the California Supreme Court decided in a 43 vote that the state alien land law constituted a violation of the California and United States constitutions. In another case in Los Angeles County, the court ruled that escheat

\footnotetext{
194 The Consulate General of Japan, Documental History of Law Cases Affecting Japanese in the United States 1916 1924, Vol. 2 (New York: Amo Press, 1978), 148.

195 Respondent's Brief, March Term 1948, Oregon State Archives, File no. 10014, 26.

196 Decree, Oregon State Archives, File No. 10014, 1.

197 Pacific Reporter Series, 204 (St. Paul: West Publishing Co., 1949), 583.

198 Earl L. Newbry, ed. State of Oregon Joumals of the Senate and House of the Forty-fifth Legislative Assembly Regular Session January 10 through April 16, 1949, (Salem: State Printing Department, 1949), 712.

${ }^{199}$ Chuman, 205-06.
} 
actions that stemmed from provisions of the alien land acts were based upon racial discrimination and violations of the Fourteenth Amendment. ${ }^{200}$

${ }^{200}$ Chuman, 218-220. In Sei Fujii v. Califormia a Japanese resident ineligible for citizenship purchased property in his name, directly violating the law. The Namba case was cited twice in the court's decision, supporting the notion that all residents have the right to earn a livelihood. 204 P. 2 d 569. 


\section{8: Conclusion}

For two generations, people of Japanese heritage who sought to make a home in the West Coast states fought countless challenges. They fought in a war for democracy in Europe in the 1940s and returned to fight their own battles for preserving democracy in their own country. With the repeal of the alien land laws, Japanese and JapaneseAmericans could not only reside in the United States, but could also subsist. While there were still battles to be fought, a new era was in sight. With a larger minority population in Oregon due to wartime migration, the legislature passed a fair employment practices acts in 1947 and 1949. Four years later Oregon passed a public accommodations act. In 1957 state legislators enacted a fair housing act. Although racial prejudice certainly existed on a personal level, the repeal of the Oregon alien land laws symbolized a desire to erase the legal signature of racism from the state's life.

In 1948 the federal Japanese-American Evacuation Claims Act granted $\$ 37$ million to those interned for lost and damaged property incurred during World War II. Forty years later Congress extended each interned family monetary reparations of $\$ 20,000$ and President George Bush wrote an apology to all recipients. "We can never fully right the wrongs of the past," Bush explained, "but we can take a clear stand for justice and recognize that serious injustices were done to Japanese Americans." In the late 1990s, 
Japanese people who lived in Peru during the war began to request reparations for being interned in the United States. ${ }^{201}$

In 1952 Congress passed the landmark McCarran-Walter Act reflecting a national trend to recognizing the injustice of discrimination based on race. Under this statute, no race could be prohibited from becoming citizens of the United States, permitting Issei to apply for citizenship. The law made Washington's Alien Land Law moot, although it was not officially removed from its legal code until $1966 .{ }^{202}$

While court rulings erased the stigma of anti-Japanese nativism, it is also important to acknowledge that World War II ushered in positive changes for Japanese Americans. For example, many Japanese decided not to return to their homes along the West Coast. Encouraged by the War Relocation Authority to move East, many found jobs or attended schools beyond the Rockies. The fact that they no longer lived in small Japanese-oriented communities diminished discriminatory reactions. In addition, the fact that all people of Japanese descent were interned during the war brought the issue of the Japanese race to national attention where exaggerated stories by West Coast papers were corrected. For succeeding generations wartime military service allowed many Nisei to take advantage of the GI Bill, attend college, and pursue professional careers.

Most important, the wartime experience taught both Americans and JapaneseAmericans that the Japanese belonged. Prior to 1941, Kennie Namba remembered, Japanese-Americans were second-class citizens. However, after the war they had the right to be in the United States not only because they were born here, but because they

201 Chuman, 240. George Bush, Washington, D. C., to Japanese evacuees, October 1990.

202 Chuman, 309. 
had sacrificed their lives out of loyalty to and love of their country. ${ }^{203}$ For Kennie, the war enabled him to go to the University of Portland. It also introduced him to his future wife, Ruth. While at Minidoka, completing high school, Kennie attended a block dance which Ruth, also interned at Minidoka, happened to attend. They reunited after Kennie was discharged and Ruth was working in Minneapolis. After the war, their parents convinced them to return to Portland and Ruth and Kennie were married in April 1946, although they had a difficult time finding someone who would marry them. The Reverend McCoy, of Hood River, performed the ceremony. Because of his support for Japanese-Americans, he was shunned by much of the Hood River Caucasian community. In fact, Ruth recalled that he had a difficult time finding a barber who would cut his hair. ${ }^{204}$

Kennie and Ruth decided to settle in Portland to raise their family. However, buying a house was a challenge. They met with a realtor who told them that some neighborhoods would not permit the sale of a house to a Japanese-American couple. Eventually, they found a new home in a marginal area of Southeast Portland. Even there, a petition had circulated in an attempt to prohibit them from moving in. ${ }^{205}$ Kennie began working for Pacific Power and Light in Portland. Although he had sufficient education and experience, he was continually passed over for promotions. Although everyday life held out repeated instances of racial discrimination for family members, the climate was improving. 
The repeal of the alien land laws reflected a tendency for racial toleration, but several other changes impacted Oregon between 1923 and 1949. While both alien land laws passed the state legislature unanimously, statewide support was much stronger in 1923. In the intense nativist climate that arose from World War I and the following Red Scare, supporters promoted the law as a moral necessity. Furthermore, many interpreted Japan's threatening imperialism in China and Russia at the turn of the century as an attempt to expand their empire throughout the world; those who claimed an invasion was occurring on the West Coast speculated that the United States was not immune to this imperialistic invasion. By 1945, Japan was a destroyed country, incapable of presenting a threat to any country. Also, the nativist climate had dissipated as America called upon all of its residents, of all races and creeds, to support the war cause. In addition, news of the Holocaust stood as a blistering example of racial prejudice. Those who urged the 1945 law's passage argued for economic reasons, not from a moral basis.

The debate that occurred prior to passage of the laws was radically different. In 1923, Japanese and commercial interests argued against the laws, yet their voices were drowned by farmers and nativists. Very little debate ensued in 1945 while Japanese were still removed in internment camps and all trade with Japan was halted during the war. Also, Japanese residents were not a customer base, or even neighbors. In fact, many citizens who had gone to school with Japanese-Americans did not realize their absence during internment. For many in Oregon, the Japanese were out-of-sight and out-ofmind. Therefore, the growing wealth of the farmers enabled their voices to be heard while the rest of Oregon's residents failed to notice. In addition, farmers had much more at stake in 1945 than in 1923, and therefore strove to make a more convincing argument. 
In 1923 farmers were struggling to recuperate from severe crop damages due to harsh winter conditions. High taxes added to the burden of farmers who found their produce receiving dwindling revenue. But in 1945, farmers found a high demand for their crops, and increasing prices. In addition, the land they owned also increased dramatically in value.

Once the legislatures passed the laws, the impact they had in 1923 contrasts sharply with the impact of the 1945 act. The writing of the 1923 law affected only the Issei, while the 1945 statute affected the Nisei because of the stipulations forbidding Issei to live with or assist their children. Also, the numerous loopholes in the first law made it tolerable, while the Issei's relationship with the Japanese consulate forced them to accept the law. Concerned that their nationals would embarrass Japan, the consulate kept a constant watch on Japanese residents, urging them to be lawful. ${ }^{206}$ In contrast, by the later time period the Nisei were the dominant generation and very few Issei were still involved in farming, as many of them had reached the age of retirement. The Nisei, unlike their parents, were American citizens and did not report to the Japanese consulate. Also, as American citizens, their education taught them the fundamentals of a democracy. Nisei believed they were not only granted the rights enjoyed by American citizens, but they had earned those privileges by serving in the armed forces and in internment camps during the war. In addition, the Nisei had the resources within society to make a change; they had the education to serve as lawyers and challenge laws, and they possessed the right to vote. With the Nisei leading the battle, the laws that had a very limited impact on the dwindling number of Issei farmers could not be upheld. 


\section{Sources}

\section{Primary Sources}

“2 Mass Meets on Japanese Problem Set." Gresham Outlook, 8 March 1945, p. 1.

"5 $5^{\text {th }}$ Column Quiz Voted by House." Oregonian, 19 February 1942, p. 1.

“Alien Land Laws Face Court Test." Oregonian, 6 April 1947, p. 1.

“Alien Ownership Effect on Titles." Oregon Voter. 16 (25 January 1919): 24-26.

Alien Property Custodian, to Renichi Fujimoto, 10 July 1945. Yasui Collection, MSS 2949, Oregon Historical Society, Portland.

“Aliens License To Be Canceled.” Sunday Oregonian, 4 January 1942, p. 6.

Allen, J. W., The Dalles, to Yasui Brothers, Hood River, 2 August 1919. Yasui Collection, MSS 2949, Oregon Historical Society, Portland.

“American Legion Urges Japanese Exclusion." Hood River News. 14 November 1919, p.1.

“Anti-Alien Bill Passes Senate.” Hood River News, 16 February 1923, p. 1.

“Anti-Alien League States Its Case." Hood River News, 1 October 1919, p. $1+$.

“Anti-Chinese." Ongon Voter 105 (17 March 1945): 6.

“The Anti-Japanese Bill." Hood River News, 16 February 1923, p. 4.

“Anti-Japanese Bill." Oregon Voter 24 (12 March 1921): 32-41.

“Anti-Japs Actives at Forest Grove." Hood River News, 2 February 1945, p. 2.

“Appellant's Brief.” October Term 1947, Oregon State Archives, File No. 10014.

“Army Ends Exclusion of Japanese." Hood River News, 22 December 1944, p. 1.

“Asiatics to be Heard." (unknown newspaper), 31 January 1923. Yasui Collection, MSS 2949, Oregon Historical Society, Portland. 
"Ban of Aliens, Citizens From Strategic Coastal Areas Asked by Group." Oregonian, 11 February 1942, p. 4.

Batchelor, F. M., San Francisco, to M. Yasui, Hood River, 24 September 1919. Yasui Collection, MSS 2949, Oregon Historical Society, Portland.

“Book Exposes Long Jap Plot.” Oregonian, 20 February 1942, p. 2.

Butts, Robert N., Chicago, to Mr. Yasui, Hood River, 3 October 1922. Yasui Collection, MSS 2949, Oregon Historical Society, Portland.

Bush, George, Washington, D. C., to Japanese Evacuees, October 1990. Private Collection.

Chambers, Ann. “The Loyal Japanese.” Oregonian, 29 January 1942, p. 8.

“Christian Scheubel." Oregon Voter 16 (4 January 1919): 59-60.

Circuit Court for the State of Oregon for the County of Multnomah. Complaint no. 175930.

Congressional Record, House. Vol. 88, Part 7. Washington, D. C.: Government Printing Office, 1942.

Connelly, Gordon M. "Survey Reveals Portland Favors Removal of Aliens." Oregonian, 12 February 1942, p. 1.

“Court Grants Bergh Ouster.” Gresham Outlook, 8 March 1945, p. 1.

Davey, Frank. Report on the Japanese Situation in Oregon. Salem: State Printing Department, 1920.

"Debate on Anti-Jap Bill." Oregon Voter. 32 (10 February 1923): 18-22.

"Debate on the Anti-Japanese Bill." Hood River News, 16 February 1923, p. 1.

"Decision Neared on Coastal Aliens." Oregonian, 20 February 1942, p. 1.

“Decree." Oregon State Archives, File No. 10014.

“Deny Japan Proposed Immigration Parley." New York Times, 6 February 1923, p. 5.

Department of Commerce. Bureau of Census. Farm Population of The United States, 1920, by Leon E. Truesdell. Washington, D. C. : Government Printing Office, 1926. 
Department of Commerce. Bureau of Census. Historical Statistics of the United States: Colonial Times to 1970, by Rogers C. B. Morton. Part I. Washington, D. C. : Government Printing Office, 1975.

Department of Commerce. Immigrants and Their Children, 1920, by Niles Carpenter. Washington, D. C. : Government Printing Office, 1927.

Department of Commerce. Seventeenth Decennial Census of United States Population, 1950. Vol. II, Part 37. Washington, D. C. : Government Printing Office, 1952.

Department of Commerce. Sixteenth Census of the United States, 1940. Vol. II, Part 5, Population. Washington, D. C. : Government Printing Office, 1943.

Department of Commerce. United States Census of Agriculture, 1925. Part III, Northerm States. Washington, D. C. : Government Printing Office, 1927.

Department of Commerce. United States Census of Agriculture, 1935. Washington, D. C. : Government Printing Office, 1936.

Department of Commerce. United States Census of Agriculture, 1945. Vol. I, Part 32, Washington and Oregon. Washington, D. C. : Government Printing Office, 1946.

Department of Commerce. United States Census of Agriculture, 1950. Vol. I, Part 32. Washington, D. C. : Government Printing Office, 1952.

Donaugh, Carl C., Portland to Ray L. Yasui, 30 July 1945. Yasui Collection, MSS 2949, Oregon Historical Society, Portland.

Dowd, Mrs. W. S. and Mr. E. Suzuki. Employment Agreement. 6 June 1936. Yasui Collection, MSS 2949, Oregon Historical Society, Portland.

“Dynamic Tax System Planned.” Oregonian, 25 January 1922, p. 1.

"Enforcement of Land Laws is Demanded." Gresham Outlook, 15 February 1945, p. 1.

“Evacuee Area to be Wider." Oregonian, 8 May 1942, p. 10.

“Farm Income." Orgon Voter 105 (11 August 1945): 9-11.

“Farm Ouster Asked by Jap." Gresham Outlook, 1 March 1945, p. 1.

“Farm and Town." Orgon Daily Journal, 26 January 1922, p. 10.

“Farmers' Union Opposes Japanese." Hood River Newss. 5 December 1919, p. 1. 
Farrell, Robert S. Jr., ed. Oregon Laws Enacted by the Forty-Third Regular Session of the Legislative Assembly Beginning January 8 and Ending Marcb 17, 1945. Salem: State Printing Department, 1945.

"FBI in Raids Seizes Alien Contraband." New York Times, 21 February 1942, p. 1.

Feike, E. Earl to M. Yaui, Hood River, 7 March 1919. Yasui Collection, MSS 2949, Oregon Historical Society, Portland.

Ferguson, Edwin E. "The California Alien Land Law and the Fourteenth Amendment." Califormia Law Review 35 (1947): 61-90.

“Frank Davey." Oregon Voter 24 (1 January 1921): 63.

Freeman, Miller. "On Wheelwright Article." Oregon Voter 21 (8 May 1920): 52-54.

"Full Text of Treaty with Japan." Oregon Voter 24 (26 March 1921): 5-12.

"Gay Fashions Displayed in Stores to Herald Spring, Easter Season." Gresham Outlook, 31 March 1949, p. 1.

“Gifford, Head of K.K.K.” Oregon Voter. 28 (25 March 1922): 5-6.

Gill, Ray W. "This War and the Farm Problem." Sunday Oregonian, 4 January 1942, p. 21.

Gram, C. H. Ninth Biennial Report of the Bureau of Labor Statistics, from October 1, 1918 to September 30, 1920. Salem: State Printing Department, 1920.

Gram, C. H. Tenth Biennial Report of the Bureau of Labor Statistics, from October 1, 1920 to September 30, 1922. Salem: State Printing Department, 1922.

“Grange View on Japanese Problem." Hood River News, 18 June 1943, p. $1+$.

“Group Asks Ban Be Put on Nippons.” Oregonian, 10 February 1945, p.1.

Gulick, Sidney L. The American Japanese Problem: A Study of the Racial Relations of the East and West. New York: Charles Scribner's Sons, 1914.

Hargrove Realty Company, Portland, to Yasui Brothers, Hood River, 25 July 1941. Yasui Collection, MSS 2949, Oregon Historical Society, Portland.

Hart, Allen. Interviewed by James Strassmaier, 15 April - 10 June 1986. Inv. 1200, transcipt. Oregon Historical Society, Portland. 
Hickle, C. A., Vermont, to Yasui Brothers, Hood River, 7 October 1919. Yasui Collection, MSS 2949, Oregon Historical Society, Portland.

Hoff, O. P. Eighth Biennial Report of the Bureau of Labor Statistics from October 1, 1916 to September 30, 1918. Salem: State Printing Department, 1918.

Hoff, O. P. Seventh Biennial Report of the Bureau of Labor Statistics from October 1, 1914 to September 30, 1916. Salem: State Printing Department, 1916.

Horowitz, David A., ed. "Minutes of the La Grande Ku Klux Klan, 1922-24." Manuscripts Collection. Oregon Historical Society, Portland.

Hood River Post No. 22, American Legion. "A Statement on the Japanese." Oregon Historical Society; Portland, n.d. Microfilm.

"How Will We Rid the Coast of the Japs?" (advertisement) Gresham Outlook, 8 March 1945, p. 5.

Intelligence Officer. "The Japanese in America: the Problem and its Solution." Harpers. 185 (October 1942):489-497.

Iyenaga, T. and Kenoske Sato. Japan and the Califormia Problem. New York: G. P. Putnam's Sons, 1921.

"Japanese Aliens Launch Trek Inland From Coast Anticipating U.S. Order." Oregonian, 5 March 1942, p. 4.

"Japanese Are Aided by Treaty." Hood River News, 28 November 1919, p. 1.

"Japanese Begin Trek to Center." Oregonian, 2 May 1942, p. 1.

"Japanese Boycott." Oregon Voter. 18 (6 September 1919): 3-4.

“Japanese Buy Hill Ranch at Dee." Hood River News, 23 February 1923, p. 1.

"Japanese Buying Land." Oregon Voter. 18 (1 November 1919): 4-5.

“Japanese Discuss Valley Situation.” Hood River News, 17 September 1919, p. 1.

“Japanese Exclusion.” Oregon Voter 105 (14 April 1945): 18-19.

“Japanese Exclusion League is Aggressive." Oregon Voter 105 (18 August 1945): 6-12.

“Japanese Exodus Starts Here Wednesday." Oregonian, 29 April 1942, p. 1.

“Japanese Move In Local Problem.” Hood River News, 1 October 1919, p. 1. 
"Japanese Proposal to Stop Agitation Meets with Delay." (unknown newspaper), 31 January 1923. Yasui Collection, MSS 2949, Oregon Historical Society, Portland.

"Japanese Statistics Food for Thought." Hood River News, 8 October 1919, p. 1.

“Japs' Farms Still Open.” Oregonian, 8 May 1942, p. 10.

“Japs Produce Big Food Quota." Oregonian, 5 March 1942, p. 1.

"Judge Declares Japanese May Live on Leased Land." Sunday Oregonian, 12 October 1947, p. 18.

Katagiri, George. Interview by Robert Gassner and Doug Magnusen, 22 February 1986. Inv. \#956, transcript. Oregon Historical Society, Portland.

Kawakami, K. K. "The Naturalization of Japanese." North American Review 185 (1907): 394-95.

“Keep Every Jap Out of Hood River Valley." Oregon Voter 105 (17 February 1945): 16-17.

“Kenji Namba v. McCourt." In Pacific Reporter. 2d series. Vol. 204. St. Paul: West Publishing Co., 1949.

“Kimono Hints Japan's Axis Partnership Dates From 1930.” Oregonian, 20 February 1942, sec. 3, p. 4.

Kozer, Sam A., ed. State of Oregon General Laws and Joint Resolutions by the Thirty-Second Regular Session of the Legislative Assembly Beginning January 8 and Ending February 11, 1923. Salem: State Printing Department, 1923.

Kuhndardt, C. P. to Mr. Yasui, Hood River, 30 October, 1919. Yasui Collection, MSS 2949, Oregon Historical Society, Portland.

"Land Transfers to Aliens Opposed." Hood River News, 6 April 1923, p. 1.

Langdon, W. A., Walla Walla, to M. Yasui, Hood River, 31 August 1933. Yasui Collection, MSS 2949, Oregon Historical Society, Portland.

"Law Assailed on Alien Land." Sunday Oregonian, 6 April 1947, p. 18.

"Legion For Exclusion of Japanese." Hood River Newss, 8 December 1944, p. 1.

"Legion Head Asks Return of Nisei Names." Hood River News, 26 January 1945, p. 1. 
“Legion May Plan Special Election.” Hood River News, 12 January 1945, p. 1.

"Legion Protests Land Sales to Aliens." Hood River News, 27 April 1923, p. 1.

“Legion Squarely Opposes Japanese.” Hood River News. 7 November 1919, p. 1.

"Letters on Japanese." Oregon Voter. 21 (29 May 1920): 43-44.

Linville, C. W. to Ray Yasui, 14 August 1945. Yasui Collection, MSS 2949, Oregon Historical Society, Portland.

Lippmann, Walter. "Queries Arise From Study of Pearl Harbor." Oregonian, 20 February 1942, p. 8.

“Local Japanese Anticipate Law.” Hood River News, 23 February 1923, p. 1.

Lundy, Herbert. "A Test for U. S. Tolerance." Sunday Oregonian, 4 January 1942, n.p.

Lynch, Jan, North Yakima, to W. J. McConnell, Moscow, ID, 21 March 1917. MSS 1500 , Oregon Historical Society, Portland.

“Mass Meeting Planned for Talk on Japs.” Gresham Outlook, 22 February 1945, p. 1.

McFarland, C. A., Portland, to Yussi Brothers, Hood River, 17 November 1928. Yasui Collection, MSS 2949, Oregon Historical Society, Portland.

McGovney, Dudley O. "The Anti-Japanese Land Laws of California and Ten Other States." Califormia Law Review 35 (1947): 7-60.

McWilliams, Carey. Prejudice: Japanese-Americans: Symbol of Racial Intolerance. Boston: Little, Brown and Company, 1945.

McWilliams, Carey. "Racism of the West Coast." The New Republic 110 (29 May 1944): 732-733.

McWilliams, Carey. "Racism of the West Coast." The New Republic 110 (12 June 1944): 784-786.

Millard, H. N. to Yasui, Hood River, May 1930. Yasui Collection, MSS 2949, Oregon Historical Society, Portland.

Moore, Mrs. Max L., to Ray Yasui, 20 August 1920. Yasui Collection, MSS 2949, Oregon Historical Society, Portland. 
Multnomah Bar Association. “The Japanese Problem in Oregon." Oregon Law Review. 24 (1944-45): 208-219.

Namba, Kennie. Interview by the author, 25 February 1999, Portland. Tape recording.

New International Mortgage Bank, LTD, Spokane, to Yasui Brothers Company, Hood River, 10 July 1939. Yasui Collection, MSS 2949, Oregon Historical Society, Portland.

Newbry, Earl T., ed. State of Onegon Journals of the Senate and House of the Forty-fifth Legislative Assembly January 10-April 16, 1949. Salem: State Printing Department, 1949.

“Nisei Names To Go Back On Honor Roll." Hood River News, 9 March 1945, p. 1.

“Nisei Soldiers' Names Erased By Local Legion.” Hood River News, 8 December 1944, p.1.

Olcott, Ben. "Message of Ben W. Olcott, Governor of Oregon, to the Thirty-first Legislative Assembly convened January 10, 1921." Salem: State Printing Department, 1921.

Olcott, Ben W., ed. State of Oregon Journals of the Senate and House of the Thirtieth Legislative Assembly, January 13-February 27, 1919. Salem: State Printing Department, 1919.

“On Wheelright Article.” Oregon Voter 21 (8 May 1920):52-54.

Oregon Governor. "Selected Papers from files of Governors, relating to Japanese in Oregon, Especially during World War II." Oregon Historical Society; Portland, n.d. Microfilm.

“Oregon Voter on Japanese Problem.” Hood River News. 7 November 1919, p. 1.

Ouchida, Jack. Interview by Linda Doami, 8 April 1995. Inv. 969. Oregon Historical Society, Portland.

“Ousting the Japanese." Onegon Voter. 32 (27 January 1923): 37-39.

"Participation in World Court Means no European Entanglement, Says President." Oregonian, 5 July 1923, p. 7.

"Pierce and Burnaugh Legislative Records." Ongon Voter 19 (16 October 1920): 42 45 .

"Pierce Slaps at Japanese." Oregonian, 10 February 1945, p. 4. 
Pierce, Walter M. "Message of Walter M. Pierce, Govemor, to the Thirty-second Legislative Assembly, convened January 8, 1923." Salem: State Printing Department, 1923.

“Platform Stated by Mr. Patterson.” Onegonian, 12 March 1922, p. 9.

“Population Given of Japanese and Chinese." Gresham Outlook, 30 January 1923, p. 1.

“Portland Japanese Reaffirm Loyalty to United States." Oregonian, 24 January 1942, p. 4.

"Public Market." Oregon Voter 18 (30 August 1919): 4.

“Public Opinion." Hood River News, 29 December 1944, p. 8.

“A Question of Racial Prejudice." Hood River News 5 January 1945, p. 6.

“Respondent's Brief.” March term 1948. Oregon State Archives, File no. 10014.

Rowell, Chester H. "Fundamental Reason for Japanese Problem." Oregon Voter. 24 (22 January 1921): 48-54.

“Says Japanese Here Are Fewer," Hood River News, 24 January 1917, p. 5.

"See Crowd at Jap Meeting." Gresham Outlook, 8 February 1945, p. 1.

Sheppard, George, Hood River, to Mr. Yasui, Hood River, February 1929. Yasui Collection, MSS 2949, Oregon Historical Society, Portland.

Shoemaker, Kent. (advertisement.) Hood River News, 23 February 1945, p. 6.

Shoemaker, Kent. (advertisment.) Hood River News, 26 January 1945, p. 10.

“Speakers Ask Sane Thought on Japanese." Gresham Outlook, 22 March 1945, p. 22.

"Start Drive to Get Funds for Campaign." Gresham Outlook, 15 March 1945, p. 10.

“State Court Voids Alien Land Law." Oregonian, 30 March 1949, p. 1.

Stegner, Wallace. "The Nisei Come Home.” The New Republic. 113 (9 July 1945): 4546.

Stoddard, Lothrop. The Rising Tide of Color: Against White World-Supremacy. New York: Charles Scribner's Sons, 1920.

"Story of the Toledo Japanese Deportation." Oregon Voter. 42 (12 September 1925): 8-16. 
"Swatting the Aliens." Oregon Voter. 32 (17 February 1923): 10-11.

"The Time to Join is Now." (advertisement.) Gresham Outlook, 15 March 1945, p. 5.

Thorpe, Eugene L. "East Multnomah Sees Yellow Peril." Sunday Oregonian, 26 November 1911, sec. 3, p. 12.

“Three Nisei Return to Valley Homes." Hood River News, 19 January 1945, p. 1+.

“Two Jap Families Back to Farms Here." Gresham Outlook 15 February 1945, p. 1.

"The Victims of Expediency." Hood River News, 22 December 1944, p. 8.

"Unanimous Against Japs." Oregon Voter 20 (24 January 1920): 4-5.

“USDA Gives Data on Jap Farm Holdings.” Hood River News, 9 March 1945, p. 10.

"Voluntary Evacuation at an End." Gresham Outlook, 2 April 1942, p. 1.

"Votes Fund to FBI to Track Japanese." New York Times. 19 February 1942, p. 11.

"War with Japan." Oregon Voter. 19 (20 December 1919): 22-25.

Wheelwright, William D. "Disapproving Anti-Japanese Agitation." Oregon Voter. 20 (14 February 1920): 5-11.

“White Help with Chinese," Oregon Voter. 16 (1 March 1919): 15.

"Wide Interest in Anti-Alien Bills." Hood River News. 21 February 1917, p. 1.

“Wilbur Withdraws Anti-Alien Bill." Hood River News. 7 February 1917, p. 1.

Wood, Lewis. "Army Gets Power to Move Citizens or Aliens Inland.” New York Times, 21 February 1942, p. $1+$.

“Would Bar Asiatics, Reduce All Quotas." Nen York Times, 6 February 1923, p. 5.

"WRA Part in Jap Problem is Explained." Hood River News 9 March 1945, p. 1.

Yasui Brothers, Hood River, to G. Charles Hodges, Stanford, 25 January 1917. Yasui Collection, Oregon Historical Society, Portland.

Yasui Brothers, Hood River, to J. F. Daley, Portland, 2 March 1923. Yasui Collection, MSS 2949, Oregon Historical Society, Portland. 
Yasui, Masuo, Hood River, to W. H. Weber, Miami Beach, 10 November 1931.

Yasui Collection, MSS 2949, Oregon Historical Society, Portland.

Yasui, Minoru. "Testimony of JACL National Commmittee for Redress." 1981. Yasui Collection, MSS 2949, Oregon Historical Society, Portland.

Yasui, Minoru. "We, too, Please, Are 100 Per Cent American." Sunday Oregonian, 4 February 1940, p. 5.

Yasui, Ray, to M. C. Hinsahw, 19 January 1945. Yasui Collection, MSS 2949, Oregon Historical Society, Portland. 


\section{$\underline{\text { Secondary Sources }}$}

Azuma, Eiichiro. "A History of Oregon's Issei, 1880-1952." Oregon Historical Quarterly. 94 (Winter 1993-94): 315-368.

Abney, David Lawrence. "Japan Bashing: A History of America's Anti-Japanese Acts, Attitudes and Laws.” Ph.D. diss. Arizona State University, 1995.

Bone, Arthur H. Oregon Cattleman/Governor Congressman: Memoirs and Times of Walter $H$. Pierre. Portland: Oregon Historical Society Press, 1981.

Burton, Robert E. Democrats of Oregon: The Pattern of Minority Politics, 1900-1956. Eugene: University of Oregon Books, 1970.

Chuman, Frank F. The Bamboo People: The Law and Japanese-Americans. Del Mar: Publisher's Inc., 1976.

The Consulate General of Japan. Documental History of Law Cases Affecting Japanese in the United States 1916-1924. Vol. 2. New York: Arno Press, 1978.

Daniels, Roger. Asian America: Chinese and Japanese in the United States Since 1850.

Seattle: University of Washington Press, 1988.

Daniels, Roger. "The Conference and Keynote Address: Relocation, Redress and the Report a Historical Appraisal." In Japanese Americans: From Relocation to Redress, ed. Roger Daniels, Sandra C. Taylor and Harry H. L. Kitano, 4-9. Salt Lake City: University of Utah Press, 1986.

Feeley, Francis. "A Legacy of Injustice: The West Coast Japanese Before World War II." Joumal of the West. 32 (October 1993): 83-91.

Fretcher, James A. "Alien Landownership in the United States: A Matter of Control." Brooklyn Journal of International Law. 14 (1988): 147-186.

Fujii, Toshimasa. "The Degree of Acculturation and Success Patterns in Three Generations of the Japanese Americans in the Portland Area." M.A. Thesis, Portland State University, 1980.

Hicks, John D. The Populist Revolt: A History of the Farmers' Alliance and the People's Party. University of Nebraska Press, 1961.

Horowitz, David A. "The Klansman as Outsider." In Pacific Northuest Quarterly 80 (January 1989): 12-21. 
Hosokawa, Bill. Nisei: The Quiet Americans. New York: William Morrow and Company, 1969.

Hosokawa, Bill. "The Uprooting of Seattle." In Japanese Americans: : From Relocation to Redress, ed. Roger Daniels, Sandra C. Taylor and Harry H. L. Kitano, 18-20. Salt Lake City: University of Utah Press, 1986.

Ichihashi, Yamato. Japanese in the United States: A Critical Study of the Problems of the Japanese Immigrants and Their Children. Stanford: Stanford University Press, 1932.

Ichioka, Yuji. The Issei: The World of the First Generation Japanese Immigrants, 1885-1924. New York: The Free Press, 1988.

Irons, Peter. Justice at War. New York: Oxford University Press, 1983.

Irons, Peter. Justice Delayed: The Record of the Japanese American Internment Cases.

Middletown: Wesleyan University Press, 1989.

Ito, Kazuo. Issei: $A$ History of Japanese Immigrants in North America. Translated by Shinichiro Nakamura and Jean S. Gerard. Seattle: Executive Committee for Publication of Issei, 1973.

Iwata, Masakazu. Planted in Good Soil: The History of the Issei in United States Agriculture. 2 Vol. New York: Peter Lang, 1992.

Jens, Charles A.., ed. Reports of Cases Decided in the Supreme Count of the State of Oregon. Vol. 185. Salem, 1949.

Johansen, Dorothy O. and Charles M. Gates. Empin of the Columbia. 2d ed. New York: Harper and Row, 1967.

Johnson, Daniel P. “Anti-Japanese Legislation in Oregon, 1917-1923.” In Oregon Historical Quarterly 97 (Summer 1996): 176-210.

Kessler, Lauren. "Guest Editor's Introduction.” In Oregon Historical Quarterly. 94 (Winter 1993-94): 311-314.

Kessler, Lauren. Stubborn Turg: Three Generations in the Life of a Japanese American Family. New York: Penguin Books, 1993.

Konvitz, Milton R. The Alien and the Asiatic in American Law. Ithaca: Cornell University Press, 1946.

Lewis, Cliff. "John Steinbeck's Alternative to Internment Camps: A Policy for the President, December 15, 1941." In Journal of the West. 34 (January 1995): 55 61. 
Loftus, Mitzi Asai. Made in Japan and Settled in Oregon. Coos Bay: Pigeon Point Press, 1990.

MacColl, E. Kimbark. The Growth of a City: Power and Politics in Portland, Oregon 1915 to 1950. Portland: The Georgian Press, 1979.

Matsuo, Hisako. "The Degree of Assimilation of the Second and Third Generation of Japanese Americans in the Portland Area." M.A. Thesis, Portland State University, 1989.

McClain, Charles, ed. Japanese Immigrants and American Law: The Alien Land Laws and Other Issues. Vol. 2. New York: Garland Publishing, Inc., 1994.

McClain, Charles J. "Tortuous Path, Elusive Goal: The Asian Quest for American Citizenship." In Asian Law Journal. 2 (May 1995): 33-60.

McKay, Floyd J. An Editor for Onegon: Charles A. Sprague and the Politics of Change. Corvallis: Oregon State University Press, 1998.

Morrison, Fred L. "Limitations on Alien Investment in American Real Estate." In Minnesota Law Review. 60 (1976): 621-668.

Myer, Dillon S. Uprooted Americans: The Japanese Americans and the War Relocation Autbority during World War II. Tucson: The University of Arizona Press, 1971.

Okihiro, Gary Y. and David Drummond. "The Concentration Camps and Japanese Economic Losses in California Agriculture, 1900-1942." In Japanese Americans: : From Relocation to Redress, ed. Roger Daniels, Sandra C. Taylor and Harry H. L. Kitano, 168-175. Salt Lake City: University of Utah Press, 1986.

Petersen, William. Japanese Americans: Oppression and Success. New York: Random House, 1971.

Powell, Linda E. "Asian Americans in Oregon: A Portrait of Diversity and Challenge." Corvallis: Oregon State Extension Service and Oregon Agricultural Experiment Station, September 1990.

Pursinger, Marvin. “Oregon's Japanese in World War II, a History of Compulsory Relocation." Ph.D. diss., University of Southern California, 1961.

Report of the Commission on Wartime Relocation and Internment of Civilians. Personal Justice Denied. 2 Vol. Washington, D. C.: Government Printing Department, 1983. 
Sayler, Lucy E. Laws Harsh as Tigers: Chinese Immigrants and the Shaping of Modern

Immigration Law. Chapel Hill: University of North Carolina Press, 1995.

Shapiro, Mark. "The Dormant Commerce Clause: A Limit on Alien Land Laws." In Brooklyn International Law Journal. 20 (1993): 217-253.

Smith, Geoffrey S. "Racial Nativism and Origins of Japanese American Relocation." In Japanese Americans: From Relocation to Redress, ed. Roger Daniels, Sandra C. Taylor and Harry H. L. Kitano, 79-87. Salt Lake City: University of Utah Press, 1986.

Spickard, Paul R. "The Nisei Assume Power: The Japanese Citizens League, 194142." In Pacific Historical Revien 52 (May 1983): 147-174.

Stearns, Marjorie R. "The History of the Japanese People in Oregon.” M.A. Thesis, University of Oregon, 1937.

Stearns, Marjorie R. "The Settlement of the Japanese in Oregon." In Oregon Historical Quarterly 30 (September 1938): 262-269.

Stevens, Beatrice. "Free and Equal? The Japanese-Americans in Oregon." Portland: A unit of work for secondary schools prepared for the workshop on intercultural education, 1945.

Strong, Edward K. Jr. The Second Generation Japanese Problem. Stanford: Stanford University Press, 1934.

Takaki, Ronald. A Different Mirnor: A History of Multicultural America. Boston: Little, Brown and Company, 1993.

Takaki, Ronald. Strangers from a Different Shore: A History of Asian Americans. Boston: Little, Brown and Company, 1989.

Tamura, Linda. The Hood River Issei: An Oral History of Japanese Settlers in Oregon's Hood River Valley. Chicago: University of Illinois Press, 1993.

Tanaka, Stefan. "The Toledo Incident: The Deportation of the Nikkei from an Oregon Mill Town.” In Pacific Nortbwest Quarterly. 69 (July 1978): 116-126.

Taylor, Sandra C. "Evacuation and Economic Loss: Questions and Perspectives." In Japanese Americans: : From Relocation to Redress, ed. Roger Daniels, Sandra C. Taylor and Harry H. L. Kitano, 163-167. Salt Lake City: University of Utah Press, 1986.

TenBroek, Jacobus, Edward N Barnhart and Floyd W. Matson. Prejudice, War and the Constitution. Berkeley: University of Califomia Press, 1968. 
Walth, Brent. Fire at Eden's Gate: Tom McCall and the Oregon Story. Portland: Oregon Historical Society Press, 1994.

Yasui, Barbara. "The Nikkei in Oregon, 1834-1940." In Oregon Historical Quarterly. 76 (September 1975): 225-257. 


\section{Appendix A}

\section{Anti-Asiatic Association of Hood River Pledge Card ${ }^{207}$}

"Believing that the rapidly increasing Japanese ownership of land in the Hood River Valley menaces our welfare, and threatens ultimate domination of our Home Land by Asiatics, I hereby apply for membership in an association to be formed and pledge myself as follows:

"That America should be preserved and protected for Americans. That no child in this country should become a citizen unless his parents belong to a race eligible to citizenship; that no one but natural born or fully naturalized citizens be allowed to own or lease land. That the Immigration of Asiatics to the United States should be prohibited.

"And further, I do pledge on my sacred honor, that I will not, either directly or indirectly, sell or lease any land which I now or hereafter own or be interested in to a person of any Asiatic race or to a corporation the majority of whose stock is held by Asiatics." 


\section{Appendix B}

\section{Informed Consent Form}

I, Ken Namba, agree to partake in this interview about my family's history. I understand that this interview may take a few hours. Amy has said that the information I can provide in this interview will be very helpful for her thesis on Alien Land Laws in Oregon. Amy has offered to answer any questions that I might have, now or later, and has provided me with a way of contacting her. I understand that if I would prefer, my name can remain anonymous in her thesis. Also, I know that my participation is completely voluntary. If at any time I change my mind, I can stop the interview without affecting my relationship with the researcher or with Portland State University. With this understanding, I agree to be interviewed.

Signature:

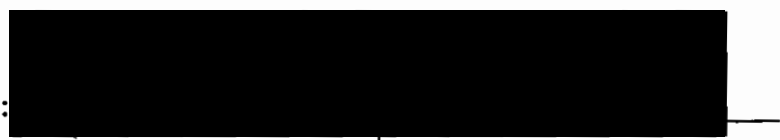

Date:

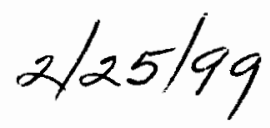

Name:

If you have concerns or problems about your participation in this study, please contact with the Human Subjects Research Review Committee, Office of Research and Sponsqrep Projects, 111 Cramer Hall, Portland State University, (503)725-8182, or Amy Buck at (503)288-1565. 
Informed Consent Form

I, Ruth Namba, agtee to partake in this interview about my family's history. I understand that this interview may take a few hours. Amy has said that the information I can provide in this interview will be very helpful for her thesis on Alien Land Laws in Oregon. Amy has offered to answer any questions that I might have, now or later, and has provided me with a way of contacting her. I understand that if I would prefer, my name can remain anonymous in her thesis. Also, I know that my participation is completely voluntary. If at any time I change my mind, I can stop the interview without affecting my relationship with the researcher or with Portland State University. With this understanding, I agree to be interviewed.
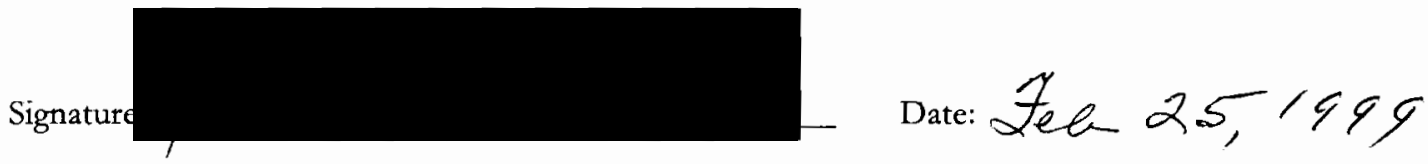

Name:

If you have concerns or problems about your participation in this study, please contact with the Human Subjects Research Review Committee, Office of Research and Sponsored Projects, 111 Cramer Hall, Portland State University, (503)725-8182, or Amy Buck at (503)288-1565. 